\title{
Kurumsal Kalitenin Gelir Dağılımı Üzerindeki Etkisi: Gelişmiş ve Gelişmekte Olan Ülkeler için Ampirik Bir Analiz ${ }^{1}$
}

\author{
Güray Akalin² \\ Ergin Uzgören ${ }^{3}$
}

Kurumsal Kalitenin Gelir Dağılımı Üzerindeki Etkisi: Gelişmiş ve Gelişmekte Olan Ülkeler için Ampirik Bir Analiz

\section{Öz}

Bu çalışmanın amacı kurumsal kalitenin gelir dağılımı üzerindeki etkisini gelişmiş ve gelişmekte olan ülkeler için araştırmaktır. Bu amaç doğrultusunda kurulan modellerde, gelir dağılımı göstergesi olarak Gini katsayısı, kurumsal yapı göstergesi olarak ise Uluslararası Ülke Risk Rehberi'nden yararlanılarak oluşturulan kurumsal kalite indeksi kullanılmıştır. 1988-2014 dönemini kapsayan yıllık verilerin kullanıldığı bu çalışmada, panel veri analizi tercih edilmiş olup, CCEMG ve Sistem GMM gibi yeni geliştirilen katsayı tahmincileri kullanılmıştır. Çalışmanın ampirik analiz kısmında elde edilen bulgular şöyle sıralanabilir: i) Kurumsal kalitedeki bir artış gelişmiş ülkelerde Gini katsayısını negatif etkilemekteyken, gelişmekte olan ülkelerde pozitif etkilemektedir. ii) Finansal gelişmişlik indeksindeki bir artış gelişmiş ülkelerde Gini katsayısını pozitif etkilemekteyken, gelişmekte olan ülkelerde negatif etkilemektedir. iii) Reel kişi başına gelirdeki bir artış hem gelişmiş hem de gelişmekte olan ülkelerde Gini katsayısını negatif etkilemektedir.

Anahtar Kelimeler: Gini Katsayısı, Kurumsal Kalite, Gelişmiş Ülkeler, Gelişmekte Olan Ülkeler
The Impact of Institutional Quality on Income Distribution: An Empirical Analysis for Developed and Developing Countries

Abstract

The objective of this study is to investigate the impact of institutional quality on income distribution among developed and developing countries. For this purpose, the Gini coefficient is used as the indicator of income distribution and the institutional quality index which was formed with the help of the International Country Risk Guide, is used as the indicator of institutional structure in models. The annual data covers 1988-2014 period that is used and recently developed panel data estimators such as CCEMG and System GMM are employed in this study. The findings obtained in the empirical analysis section can be listed as follows: i) An increase in institutional quality affects the Gini coefficient negatively in developed countries while affects positively in developing countries. ii) An increase in the financial development index affects the Gini coefficient positively in developed countries while affects negatively in developing countries. iii) An increase in real income per capita affects the Gini coefficient negatively in both developed and developing countries.

Keywords: Gini Coefficient, Institutional Quality, Developed Countries, Developing Countries

\section{Giriş}

İtisadi aktivitelerin ve iktisat politikalarının temel hedefi toplumu oluşturan bireylerin refah seviyesini arttırmaktır. Refah seviyesi genellikle reel kişi başına gelir düzeyi üzerinden hesaplandığından, refah artışı açısından üretimi arttırmak yani iktisadi büyümeyi sağlamak çok kritik bir öneme sahiptir. Ancak gelirin bireyler arasında eşit dağılmaması durumunda, reel kişi başına gelir toplumun refah seviyesini doğru yansıtmadığı gibi iktisadi büyüme de toplumsal refahı istenilen düzeyde artırmayacaktır. Çünkü gelir dağılımı eşitsizliğinin yüksek olduğu durumlarda

\footnotetext{
${ }^{1}$ Bu çalışma, Kütahya Dumlupınar Üniversitesi, Sosyal Bilimler Enstitüsü, İktisat Anabilim Dalı'nda Prof. Dr. Ergin Uzgören danışmanlığında, Güray Akalin tarafından "Kurumsal Kalitenin Gelir Dağılımı Üzerindeki Etkisi: Gelişmiş ve Gelişmekte Olan Ülkeler için Ampirik Bir Analiz" ismiyle tamamlanarak 01.08.2018 tarihinde savunulan doktora tezinden türetilmiştir.

${ }^{2}$ Arş. Gör. Dr., Kütahya Dumlupınar Üniversitesi, iiBF, İktisat Bölümü. guray.akalin@dpu.edu.tr, yazar ORCID bilgisi: http://orcid.org/0000-0002-8286-0420.

3 Prof. Dr., Kütahya Dumlupınar Üniversitesi, iiBF, İktisat Bölümü. ergin.uzgoren@dpu.edu.tr, yazar ORCID bilgisi: https://orcid.org/0000-0001-9031-9768.
} 
iktisadi büyümenin nimetlerinden büyük ölçüde toplumun belirli kısmı yararlanacaktır. Bu ise bireyler arası refah farklılıklarının daha da artmasına neden olacaktır. Dolayısıyla, iktisadi birimlerin refah seviyesinin arttırılabilmesi için üretim kadar öneme sahip bir diğer konunun ise gelir dağılımı olduğu anlaşılmaktadır. Ünlü iktisatçı Thomas PIKETTY "Yirmi Birinci Yüzyılda Kapital” adlı kitabında gelir dağılımının önemini şu sözlerle belirtmektedir (Piketty, 2014a: 2): "Zenginliğin bölüşümü sorunu yalnızca ekonomistlere, sosyologlara, tarihçilere ve diğer düşünürlere emanet edilemeyecek kadar önemlidir". Gelir dağılımı yalnızca toplumsal refah ile değil sosyal barış ve istikrar, sürdürülebilir iktisadi büyüme ve yoksulluk ile de doğrudan bağlantılıdır (Barro, 2000; Naschold, 2000; Stiglitz, 2015). Bu nedenle de gelir dağılımının dinamikleri iktisatçılar tarafından uzun yıllardır incelenmekte ve gelir dağılımı eşitsizliğini açıklamaya yönelik çeşitli teoriler geliştirilmektedir ${ }^{4}$.

Gelir dağılımı eşitsizliğini açıklamaya yönelik geliştirilen bu teoriler daha çok ana akım iktisat varsayımlarına dayandığından, birçoğunda kurumların gelir dağılımı üzerindeki olası etkilerinin dikkate alınmadığı görülmektedir. Oysa 19. yüzyılın sonu ve 20. yüzyılın başlarında ortaya çıkan ve kurumları iktisat bilimi dışında bıraktıkları için ana akım iktisadı eleştiren kurumsal iktisat yaklaşımına göre kurumlar kaynak tahsisi, makroekonomik değişkenlerin ve gelir dağılımının incelenmesi gibi süreçlerden bağımsız varsayılamaz. Çünkü kurumsal iktisada göre iktisadi işleyişin ve sistemlerin temelini ana akım iktisadın varsaydığı gibi bireyler değil kurumlar oluşturmaktadır (Demir, 1996: 64-69; Hodgson, 2000: 317; Chavance, 2009: 1). Kurumsal iktisadın bu temel varsayımının kabul görmesi ve kurumsal yapının ölçülmeye başlanması ile birlikte özellikle yirminci yüzyılın sonlarına doğru kurumlar, iktisadi analiz içindeki yerlerini almış ve ülkelerin kurumsal yapıları ile ekonomik performansları arasındaki ilişki yoğun bir şekilde incelenmeye başlanmıştır. Fakat ilgili literatür incelendiğinde daha çok kurumlar ile iktisadi büyüme arasındaki ilişkinin incelendiğ $\mathrm{i}^{5}$, kurumlar ile gelir dağılımı arasındaki ilişkiyi inceleyen çalışma sayısının ise çok sınırlı olduğu görülmektedir. Oysa ekonomik ve politik süreçleri yöneten kurumlar, kişisel teşvikleri etkiledikleri ve bireylerin üstlenebilecekleri faaliyetleri sınırladıkları için kişisel gelirleri de etkilemektedirler (Amendola vd., 2013: 44; Chong ve Calderon 2000a: 761).

Bu çerçevede, çalışmanın amacı kurumsal kalitenin gelir dağılımı üzerindeki etkisini gelişmiş ve gelişmekte olan ülkeler için incelemektir. Uluslararası literatürde bu konuda yapılmış çalışma sayısının çok sınırlı olması, kapsamlı bir çalışmanın bulunmaması ve Türkçe literatürde ilgili konuda herhangi bir çalışmaya rastlanılmamış olması bizi bu çalışmayı yapmaya teşvik etmiş ve çalışmanın ana motivasyonunu oluşturmuştur. Bu araştırmanın literatüre üç önemli noktada katkı sağlayacağı düşünülmektedir. i) Araştırıldığı kadarıyla literatürdeki çalışmaların tamamı yatay kesit bağımlıı̆ıını dikkate almayan birinci nesil ekonometrik araçlar kullanmaktadır. Bu çalışmada yakın zamanda geliştirilen ikincil nesil ekonometrik araçlar kullanılarak elde edilen bulguların daha tutarlı ve etkin olması amaçlanmıştır. ii) Araştırıldığı kadarıyla literatürde kurumsal kalitenin gelir dağılımı üzerindeki etkisini farklı gelir düzeylerine sahip ülkeler için ayrı ayrı inceleyen çalışma sayısı çok yetersizdir. Bu çalışmada kurumsal kalitenin gelir dağılımı üzerindeki etkisi gelişmiş ve gelişmekte olan ülkeler için ayrı ayrı incelenerek literatürdeki bu boşluk doldurulmaya çalışımıştır. iii) Literatürdeki çalışmaların büyük bir çoğunluğu kurumsal yapıyı oluşturan unsurlardan biri ya da bir kaçı ile gelir dağııımı arasındaki ilişkiyi incelemektedir. Bu

\footnotetext{
${ }^{4}$ Ayrıntılı bilgi için SAHOTA (1978)'nın “Theories of Personal Income Distribution: A Survey,” adlı çalışması incelenebilir.

${ }^{5}$ North 1991; Barro, 1991; Abrams ve Lewis, 1995; Knack ve Keefer, 1995; Hall ve Jones, 1999;; Acemoglu, Johnson ve Robinson, 2002; Rodrik, Subramanian ve Trebbi, 2004; Acemoglu, Cutler, Finkelstein ve Linn, 2006; Haggard ve Tiede, 2011; Dias ve Tebaldi, 2012; Nawaz, 2015.
} 
çalışmada beş faklı kurumsal yapı göstergesi bir araya getirilerek konu daha geniş bir perspektiften ele alınmıştır.

\section{Teorik Çerçeve}

Diğer birçok iktisadi konuda olduğu gibi gelir dağılımı konusunda da kurumsal iktisatçılar ile ana akım iktisatçılar arasında önemli görüş farklılıkları söz konusudur. Bu kapsamda, ana akım iktisatçılar daha çok gelirin üretim faktörleri arasında nasıl dağıldığı (fonksiyonel gelir dağılımı) ile ilgilenmekteyken, kurumsal iktisatçılar gelirin hane halkları veya kişiler arasında nasıl dağıldığı (kişisel gelir dağıımı) ile ilgilenmektedirler. Neo-klasik iktisatçılara göre üretim faktörleri üretimden, üretime yaptıkları marjinal katkı paralelinde gelir elde etmektedirler. Neo-Keynesyen teoriler ise merkezine çıktının emek ve sermaye arasındaki dağılımını almışlardır. Ancak, kurumsal iktisatçılara göre gelirin bireyler arasındaki dağılımı, büyük ölçüde toplumdaki güç ilişkilerini içeren ihtiyari kurumsal düzenlemeler tarafından belirlenmektedir ve bu nedenle dağılım meselesi sadece üretime yapılan katkı ile yani nesnel ya da teknik ifadelerle açıklanamaz (Park, 1996: 88). Stiglitz (2016)'de bu yönde bir çıkarımda bulunmakta ve standart iktisat teorisinin kurumsal farklılıkları dikkate almamasından dolayı benzer teknolojilere, verimliliğe ve kişi başına gelire sahip ülkelerdeki gelir dağılımı farklılıklarını açıklayamayacağını ileri sürmektedir (Stiglitz, 2016: 6). Ayrıca Stiglitz'e göre son üç yüz yılda ücretlerin verimlilikten daha az artması, gelir dağılımı farklııklarını açıklamak amacıyla geliştirilen marjinal verimlilik teorisinin geçersizliğini kanıtlar niteliktedir (Stiglitz, 2016: 10). Asıl kurumsal iktisadın kurucusu Veblen (1908)'de John Bates Clark'ın marjinal üretkenliğini ciddi şekilde eleştirmiştir. Bununla birlikte Veblen, Commons ve Ayres gibi ilk kurumsal iktisatçıların doğrudan gelir dağılımı ile ilgilenmedikleri ve gelir dağılımı ile ilgili görüşlerinin teknolojinin doğası, mülkiyetin ortaya çıkışı ve sermayenin anlamına yönelik gerçekleştirilen çalışmaların içinde yerleşik olduğu görülmektedir. Çağdaş kurumsal iktisatçıların ise dağılım üzerinde şekillendirici olabilecek sosyal ve/veya teknolojik faktörler üzerine çalışmaları bulunmaktadır (Brown, 2005: 915).

Samuels (1999)'e göre dağıım kurumların, kurumlar ise dağılımın bir fonksiyondur. Yani iki değişken arasında çift yönlü bir nedensellik söz konusudur. Bu kapsamda, kurumlar ekonomide kimin çıkarlarının korunacağını, kimlerin üretilen mal ve hizmetlere ulaşacağını, bölüşümün piyasada nasıl gerçekleşeceğini belirlemekte ve bu yolla dağılımı doğrudan etkilemektedir. Yine, kurumlar sayesinde, iktisadi ajanlar refahlarının bir göstergesi olan varlıklarını yönetebilmekte, kurumsal yaklaşımların kurumsal bir süreç olarak gördükleri piyasalarda şekilsel, yapısal ve işlemsel faaliyetlerini gerçekleştirebilmektedirler. Gelir ve refahın dağılımı ise kurumların güvenirliliği ve evrimi yoluyla düzeni hükmü altına alarak kurumları etkilemektedir (Samuels, 1999; Aktaran: Oğuz, 2017:143). Samuels (1999) ile benzer şekilde Brown (2005)'da dağıtım mekanizmalarının davranışlardan, geleneklerden, çalışma hayatındaki kurallardan, kanunlar ve inanç sistemlerinden, yani kurumsal düşünce yapısından ayrılamaz bir parça olduklarını belirtmektedir (Brown, 2005: 920). Piketty ve Saez (2014) ise gelir dağılımı eşitsizliğinin Marks ve Kuznets'in ileri sürdüğü gibi deterministik bir süreç izlemediğini, gelir dağılımı eşitsizliğinin hem zaman içinde hem de ülkeler arasında önemli değişmeler gösterebildiğini belirtmektedirler. Yazarlara göre gelir dağılımı eşitsizliğinin hangi yönde hareket edeceği ise toplumların benimsemeyi tercih ettiği kurum ve politikalara bağlı olmaktadır (Piketty ve Saez, 2014b: 838-843).

Amendola vd. (2013)'e göre politik ve ekonomik süreçleri yöneten kurumlar, kişisel teşvikleri yönlendirdikleri ve bireylerin üstlenebilecekleri faaliyet alanlarını belirledikleri için kişisel gelirleri de etkilemektedir (Amendola vd., 2013: 44). Bu çerçevede, Stiglitz (2016)'e göre kurumsal kalitedeki bir artış rant arama faaliyetlerini ve iktisadi ayrımcılığı kısıtladığından, daha iyi 
düzenlenmiş finansal sisteme ve daha güçlü işçi haklarına vesile olduğundan gelir dağılımı eşitsizliğinin azalmasına sebep olmaktadır. Baligh ve Piraee (2012)'de kurumsal kalitenin, finansal sistem üzerinde önemli bir etkisinin olduğunu vurgulamaktadır. Buna göre, kurumsal kalitenin düşük olduğu toplumlarda geliri düşük bireyler finansal sistemden dışlanmaktayken, finansal sistemin sunmuş olduğu olanaklar teminat sunabilen, geri ödeme olasılı̆̆ı daha yüksek zengin ve iyi bağlantıları olanlara kanalize edilmektedir. Bu ise ülkeler gelişmiş finansal sistemlere sahip olsalar dahi, düşük gelirli bireylerin hem beşeri hem de ekonomik yatırımları için gerekli sermayeye ulaşamamalarına ve gelir dağılımı eşitsizliğinin artmasına ve bir sonraki nesile aktarılmasına neden olmaktadır (Baligh ve Piraee, 2012: 58). Zhou ve Song (2016)'a göre ise kurumsal kaliteyi artıracak reformlar gelir dağılımını rekabet kanalı ile etkilemektedir. Buna göre kurumsal kalitedeki artışlar, monopol durumdaki piyasalara giriş engellerini ve iyi bağlantılı kişileri koruyan yasaları kaldırarak, tarafların eşit koşullarda rekabet etmesini sağlayacaktır. Bu ise hem monopol rantlarını ortadan kaldırarak, hem daha adil bir ücret yapısına yol açarak, hem de daha az ayrıcalıklı düşük bireylere ekonomik fırsatlar sunarak gelir dağılımı eşitsizliğini azaltacaktır (Zhou ve Song, 2016: 200-201). Ayrıca, kurumsal kalitedeki bir artış yoksulların haklarının daha iyi korunmasına, devletten daha iyi hizmet talep etmelerine ve sahip olması gerektikleri kamu mallarının daha büyük bir kısmını gerçekte teslim almalarına olanak sağlayarak da gelir dağıımı eşitsizliğini azaltmaktadır (Khan, 2009: 9).

Chong ve Calderon (2000a)'e göre bireyler arası etkileşimleri biçimlendiren kuralların sürekli değişmesi ya da bunlara uyulmaması, sözleşmelerin tarafsız uygulanmaması, hükümetlerin takdir yetkisinin sınırsız olması, mülkiyet haklarının yeterince güvence altına alınmaması, yolsuzluğun yüksek olması, yozlaşmış bürokrasi nedeniyle fakirlerin korunamaması kurumsal kalite ile ilgili bir sorun olduğu anlamına gelmektedir. Çünkü böyle bir kurumsal ortamda hizmet sunumu, adil bir yargı sistemi ve kaynakların tahsisi istenilen düzeyin altında olmakta ve gerçek başarı amaçlanandan düşük olmaktadır (Chong ve Calderon, 2000a: 761). Kurumsal yapıdaki bu tür bozukluklar ayrıca iktisadi büyümenin nimetlerinin yalnızca ayrıcalıklı bir kesimin eline geçmesine, toplumunun geriye kalan önemli bir kısmının gelirinin ise düşmesine neden olmaktadır. Böylece bir yandan gelir dağılımı eşitsizliği artmakta bir yandan da mutlak yoksulluk yükselmektedir (Chong ve Calderon, 2000b: 125). Ancak, Chong ve Calderon (2000a)'e göre kurumsal kalite ile gelir dağılımı arasındaki ilişki doğrusal olmayabilir. Zira yazarlar yapmış oldukları ampirik analiz kapsamında, kurumsal kalitenin görece daha yüksek olduğu gelişmiş ülkelerde kurumsal kalitedeki bir artışın gelir dağılımı eşitsizliğini azalttığını, kurumsal kalitenin görece daha düşük olduğu gelişmekte olan ülkelerde ise kurumsal kalitedeki bir artışın gelir dağılımı eşitsizliğini arttırdığını tespit etmişlerdir. Yazarlar, gelişmekte olan ülkeler için elde ettikleri bu bulguyu, gelişmekte olan ülkelerde kayıt dışı ekonomin görece daha yüksek olması ve düşük gelirli bireylerin çoğunluğunun bu alanda faaliyet gösteriyor olması ile açıklamaktadır. Buna göre, hukukun üstünlüğündeki ve vergi tahsilatındaki gelişmeler, yeni vergiler, aşırı bürokrasinin ve yolsuzluğun azaltılması gibi kurumsal kalitede artışa sebep olacak kurumsal reformlar, kayıt dışı ekonomi üyelerine yüksek işlem maliyeti getirmekte ve kayıt dışı ekonominin faaliyet gösterdiği sistemi zayıflatmaktadır. Bu ise başlangıçta bir yandan kayıt dışı sektörlerde faaliyet gösteren düşük gelirli bireylerin gelirlerinin mutlak ve görece azalmasına, bir yandan da resmi sektörlerde faaliyet gösterenlerin kazançlarının mutlak ve görece artmasına neden olmakta ve gelir dağılımı eşitsizliği artmaktadır. Yazarlara göre, reformların sonraki aşamalarında, başlangıç kazançlarının ortadan kalkması, kayıt dışı ekonominin oyunun yeni kurallarına uyum sağlaması ve bu alanda faaliyet gösteren düşük gelirli bireylerin resmi işlerde çalışmaya başlaması ile birlikte gelir dağılımı eşitsizliği tekrar azalmaktadır (Chong ve Calderon, 2000a: 781). 


\section{Ampirik Literatür Taraması}

Kurumsal kalitenin gelir dağılımı üzerindeki etkisini inceleyen ampirik çalışmaların 2000'den itibaren yapıldığı ve sayılarının sınırlı olduğu görülmektedir. Bu çalışmaların önemli bir kısmı aşağıda yer alan Tablo 1 'de sunulmaktadır.

Tablo 1: Ampirik Literatür

\begin{tabular}{|c|c|c|c|c|}
\hline Yazar(lar) & Örneklem ve Dönem & Bağımlı Değişken & Bağımsız Değişken(ler) & Sonuç \\
\hline \multirow[t]{2}{*}{ Barro (2000) } & \multirow[t]{2}{*}{100 Ülke; 1960-1990 } & \multirow[t]{2}{*}{ Gini Katsayısı } & Demokrasi & Negatif Etki \\
\hline & & & Hukukun Üstünlüğü & Negatif Etki \\
\hline $\begin{array}{l}\text { Chong ve Calde- } \\
\text { ron (2000a) }\end{array}$ & 105 Ülke;1982-1995 & Gini Katsayısı & Kurumsal Kalite İndeksi ${ }^{6}$ & $\begin{array}{l}\text { Ters U ilişkisi } \\
\text { mevcut. }\end{array}$ \\
\hline Li vd. (2000) & 47 Ülke;1980-1992 & Gini Katsayısı & Yolsuzluk & $\begin{array}{l}\text { Ters U ilişkisi } \\
\text { mevcut. }\end{array}$ \\
\hline Gupta vd. (2002) & 39 Ülke;1980-1997 & Gini Katsayısı & Yolsuzluk & Pozitif Etki \\
\hline Cogneau ve & 73 Avrupa Dışı Ülke; & Gini Katsayısı & Hukukun Üstünlüğü & Negatif Etki \\
\hline Guénard (2003) & 1980-1989 & & & \\
\hline $\begin{array}{l}\text { Reveny ve Li } \\
\text { (2003) }\end{array}$ & 69 Ülke; 1960-1996 & Gini Katsayısı & Demokrasi & Negatif Etki \\
\hline Chong (2004) & 51 Ülke; 1960-1995 & Gini Katsayısı & Demokrasi & $\begin{array}{l}\text { Ters U ilişkisi } \\
\text { mevcut }\end{array}$ \\
\hline \multirow{2}{*}{$\begin{array}{l}\text { Chong ve Grads- } \\
\text { tein (2007) }\end{array}$} & \multirow[t]{2}{*}{121 Ülke;1960-2007 } & \multirow[t]{2}{*}{ Gini Katsayısı } & Gastil İndeksi & Negatif Etki \\
\hline & & & Kurumsal Kalite İndeksi ${ }^{7}$ & Negatif Etki \\
\hline \multirow[t]{3}{*}{ Afonso vd. (2008) } & 18-22 OECD Üا- & Alt \%40’lık Kesi- & Yargının Bağımsızlığı & I.O.A.E. \\
\hline & \multirow[t]{2}{*}{ kesi;1960-2000 } & \multirow[t]{2}{*}{$\begin{array}{l}\text { min Gelirden Al- } \\
\text { dığı Pay }\end{array}$} & $\begin{array}{l}\text { Bürokratik İşlemlerin Mik- } \\
\text { tarı }\end{array}$ & I.O.A.E. \\
\hline & & & Düzenleme Kalitesi & I.O.A.E. \\
\hline Carmignani (2009) & 120 Ülke;1970-2000 & Gini Katsayısı & $\begin{array}{l}\text { Ekonomik Özgürlük İn- } \\
\text { deksi }\end{array}$ & Negatif Etki \\
\hline Wagle (2009) & 5 Ülke;1980-2013 & Gini Katsayısı & Demokrasi & Pozitif Etki \\
\hline Apergis vd. (2010) & $\begin{array}{l}\text { ABD'deki } 50 \text { Eya- } \\
\text { let;1980-2004 }\end{array}$ & Gini Katsayısı & Yolsuzluk & Pozitif Etki \\
\hline Bircan vd. (2010) & 128 Ülke;1960-2004 & Gini Katsayısı & İçsel Çatışmalar & Pozitif Etki \\
\hline $\begin{array}{l}\text { Andres ve Ramlo- } \\
\text { gan-Dobson } \\
\text { (2011) }\end{array}$ & $\begin{array}{l}19 \text { Latin Amerika Ül- } \\
\text { kesi;1982-2002 }\end{array}$ & Gini Katsayısı & Yolsuzluk & Negatif Etki \\
\hline \multirow[t]{2}{*}{ Delis vd. (2012) } & \multirow[t]{2}{*}{91 Ülke;1973-2005 } & Gini Katsayısı ve & Hukuk ve Düzen & Negatif Etki \\
\hline & & Theil İndeksi & Şeffaflık & Negatif Etki \\
\hline \multirow[t]{6}{*}{ Oloufade (2012) } & \multirow[t]{6}{*}{39 G.O.Ü. 1984-1999 } & \multirow[t]{6}{*}{ EHII } & Yolsuzluk & I.O.A.E. \\
\hline & & & Demokrasi & Negatif Etki \\
\hline & & & Askerin Politika İçindeki & Pozitif Etki \\
\hline & & & Yeri & \\
\hline & & & İçsel Çatışmalar & Pozitif Etki \\
\hline & & & Dışsal Çatışmaar & Pozitif Etki \\
\hline $\begin{array}{l}\text { Amendola vd. } \\
\text { (2013) }\end{array}$ & 62 G.O.Ü. 1970-2004 & Gini Katsayısı & Mülkiyet Hakkı Güvencesi & Pozitif Etki \\
\hline $\begin{array}{l}\text { Perera ve Lee } \\
\text { (2013) }\end{array}$ & 9 G.O.Ü. 1985-2009 & Gini Katsayısı & Kurumsal Kalite İndeksi ${ }^{8}$ & I.O.A.E. \\
\hline \multirow[t]{2}{*}{ Adeleye (2014) } & \multirow[t]{2}{*}{137 Ülke; 2000-2012 } & \multirow[t]{2}{*}{ Gini Katsayısı } & Hukuk ve Düzen & Negatif Etki \\
\hline & & & Yolsuzluzluğun Kontrolü & Pozitif Etki \\
\hline
\end{tabular}

6 Kamulaştırma riski, hükümet tarafından sözleşmenin inkârı, hukuk ve düzen, yolsuzluk ve bürokrasi kalitesi göstergelerinin basit ortalaması alınarak hesaplanmıştır.

${ }^{7}$ Demokratik hesap verilebilirlik, yolsuzluk, hukuk ve düzen, hükümet istikrarı ve bürokrasi kalitesi göstergelerinin basit ortalaması alınarak hesaplanmıştır.

${ }^{8}$ Demokratik hesap verilebilirlik, yolsuzluğun kontrolü, hukuk ve düzen, bürokrasi kalitesi ve hükümet istikrarı değişkenlerinin basit ortalaması alınarak hesaplanmıştır. 


\begin{tabular}{|c|c|c|c|c|}
\hline $\begin{array}{l}\text { Batuo ve Asongu } \\
(2015)\end{array}$ & $\begin{array}{l}28 \text { Afrika Ülkesi;1996- } \\
2010\end{array}$ & Gini Katsayısı & Kurumsal Kalite İndeksi ${ }^{9}$ & Pozitif Etki \\
\hline $\begin{array}{l}\text { Hartmann vd. } \\
(2015)\end{array}$ & 150 Ülke;1962-2012 & Gini Katsayısı & $\begin{array}{l}\text { Politik İstikrar } \\
\text { Yolsuzluğun Kontrolü } \\
\text { Hükümet Etkinliği } \\
\text { Düzenleme Kalitesi } \\
\text { Düşünce özgürlüğü ve He- } \\
\text { sap Verilebilirlik }\end{array}$ & $\begin{array}{l}\text { Negatif Etki } \\
\text { I.O.A.E. } \\
\text { I.O.A.E. } \\
\text { I.O.A.E. } \\
\text { I.O.A.E. }\end{array}$ \\
\hline $\begin{array}{l}\text { Khosroabadi vd. } \\
\text { (2015) }\end{array}$ & $\begin{array}{l}\text { Seçilmiş Güney Asya, } \\
\text { OECD ve OIC Ülke- } \\
\text { leri;1999-2010 }\end{array}$ & Gini Katsayısı & $\begin{array}{l}\text { Politik İstikrar } \\
\text { Şeffaflık ve Hesap Verile- } \\
\text { bilirlik } \\
\text { Hukuk ve Düzen } \\
\text { Demokrasi } \\
\text { Yolsuzluğun Kontrolü }\end{array}$ & $\begin{array}{l}\text { Negatif Etki } \\
\text { Negatif Etki } \\
\text { Negatif Etki } \\
\text { I.O.A.E. } \\
\text { Negatif Etki }\end{array}$ \\
\hline $\begin{array}{l}\text { Park ve Mercado } \\
\text { (2015) }\end{array}$ & $\begin{array}{l}37 \text { Asya Ülkesi; 2004- } \\
2012\end{array}$ & Gini Katsayısı & Hukukun Üstünlüğü & Pozitif Etki \\
\hline $\begin{array}{l}\text { Adams ve Klo- } \\
\text { bodu (2016) }\end{array}$ & $\begin{array}{l}21 \text { Sahra Altı Afrika Ül- } \\
\text { kesi; 1985-2011 }\end{array}$ & Gini Katsayısı & $\begin{array}{l}\text { Yolsuzluğun Kontrolü } \\
\text { Şeffaflık İndeksi }\end{array}$ & $\begin{array}{l}\text { Negatif Etki } \\
\text { Negatif Etki }\end{array}$ \\
\hline $\begin{array}{l}\text { Anyanwu vd. } \\
\text { (2016) }\end{array}$ & $\begin{array}{l}17 \text { Batı Afrika Ülkesi; } \\
\text { 1970-2011 }\end{array}$ & Gini Katsayısı & $\begin{array}{l}\text { Demokrasi } \\
\text { İçsel Çatışmalar }\end{array}$ & $\begin{array}{l}\text { Negatif Etki } \\
\text { Pozitif Etki }\end{array}$ \\
\hline $\begin{array}{l}\text { Benneth ve Niko- } \\
\text { laev (2016) }\end{array}$ & 98 Ülke;1990-2010 & Gini Katsayısı & Hukukun Üstünlüğü & Negatif Etki \\
\hline $\begin{array}{l}\text { Afesorgbor ve } \\
\text { Mahadevan } \\
(2016)\end{array}$ & 68 Ülke;1960-2008 & Gini Katsayısı & $\begin{array}{l}\text { Demokrasi } \\
\text { İnsan Hakları } \\
\text { İçsel Çatışmalar }\end{array}$ & $\begin{array}{l}\text { Negatif Etki } \\
\text { Pozitif Etki } \\
\text { I.O.A.E. }\end{array}$ \\
\hline Lee ve Lee (2018) & 110 Ülke;1984-2013 & Gini Katsayısı & Kurumsal Kalite İndeksi ${ }^{10}$ & $\begin{array}{l}\text { D.M.'de ne- } \\
\text { gatif } \\
\text { etki/K.M.'de } \\
\text { ters U İlişkisi }\end{array}$ \\
\hline
\end{tabular}

Kısaltmalar: G.O.Ü: Gelişmekte Olan Ülkeler, I.O.A.E. : İstatistiki Olarak Anlamsız Etki, D.M.: Doğrusal Model, K.M.: Kuadratik Model

Ampirik literatür tablosu incelendiğinde, bulgular itibariyle literatürdeki çalışmaların dört gruba ayrıldığı görülmektedir. Bunlardan birincisi; kurumsal kalitedeki artışın gelir dağılımı eşitsizliğini azaltacağı bulgusunu elde eden çalışmalar, ikincisi; kurumsal kalitedeki artışın gelir dağılımı eşitsizliğini arttırdığı bulgusunu tespit edenler çalışmalar, üçüncüsü; kurumsal kalite ile gelir dağılımı arasında ters $U$ şeklinde ilişki tespit edenler çalışmalar, dördüncüsü ise kurumsal kalitenin gelir dağılımı üzerindeki etkisinin istatistiki olarak anlamsız olduğunu tespit eden çaış̧malardır. Dolayısıyla, literatürde kurumsal kalitedeki bir değiş̧imin gelir dağılımında nasıl bir değişime yol açacağı hususunda henüz bir uzlaşının var olmadığı söylenebilir. Bu ise ilgili konuda daha fazla çalışma yapılması gerekliliğini ortaya çıkarmaktadır.

\section{Model ve Yöntem}

Çalışmada, gelişmiş ve gelişmekte olan ülkelerde kurumsal kalitenin gelir dağılımı üzerindeki etkisi, aşağıda yer alan 1 numaralı tam logaritmik doğrusal model ve 2 numaralı dinamik tam logaritmik doğrusal model aracılığıyla araştırılmaktadır. Tam logaritmik doğrusal modelin tercih

\footnotetext{
${ }^{9}$ Düşünce özgürlüğü ve hesap verilebilirlik, yolsuzluğun kontrolü, politik istikrar, hükümetin etkinliği, düzenleme kalitesi ve hukukun üstünlüğü göstergeleri kullanılarak temel bileşenler analizi (principal component analysis) yöntemi ile elde edilmiştir.

${ }^{8}$ Kurumsal kalite göstergesi olarak ICRG tarafından yayımlanan ekonomik, politik ve finansal risk indeksleri kullanılmıştır.
} 
edilmesinin sebebi; yatay kesit bağımlılığı dikkate alabilmek iken, dinamik tam logaritmik doğrusal modelin tercih sebebi; literatürde yavaş değiştiği ve bu nedenle de geçmiş değerlerinden etkilendiği kabul edilen gelir dağılımını daha iyi açıklayabilmektir.

$$
\begin{aligned}
& G_{i, t}=\beta_{0}+\beta_{1} I_{i, t}+\beta_{2} Y_{i, t}+\beta_{3} F D I_{i, t}+\varepsilon_{1 i, t} \\
& G_{i, t}=\beta_{0}+\beta_{1} G_{i, t-1}+\beta_{2} I_{i, t}+\beta_{3} Y_{i, t}+\beta_{4} F D I_{i, t}+\varepsilon_{1 i, t}
\end{aligned}
$$

Burada, Git, her bir kesite ait Gini katsayısını, Git-1, her bir kesite ait Gini katsayısının gecikmesini, $\mathbf{l}_{i t}$, her bir kesite ait kurumsal kalite indeksini, $\mathbf{Y}_{\text {it, }}$, her bir kesite ait kişi başına reel geliri, FDl $_{i t}$ ise her bir kesite ait finansal gelişmişlik indeksini ifade etmektedir. Bu çalışma kapsamında iki farklı örneklem oluşturulmuştur. Bu örneklemlerden birincisi 29 gelişmiş ülkeyi ${ }^{11}$, ikincisi ise 24 gelişmekte olan ülkeyi ${ }^{12}$ kapsamaktadır. Çalışmada, 1988-2014 dönemini kapsayan yıllık veriler kullanılmış olup, dengeli panel tercih edilmiştir.

Gelir dağılımı eşitsizliğini temsilen çalışmada kullanılan bağımlı değişken, ampirik literatürde yaygın olarak kullanılan Gini katsayısıdır. Gini katsayısına ait veriler Gini katsayısının en kapsamlı veri tabanı olan Standartlaştırılmış Dünya Gelir Eşitsizliği Veritabanı (SWIID-Standardized World Income Inequality Database)'nından elde edilmiştir. Asıl kurumsal iktisadın kurucusu Veblen (1919)'in "yaygın düşünce alışkanlıkları", yeni kurumsal iktisadın kurucusu North (1999)'un ise "oyunun kuralları" olarak tanımladıkları kurumların kapsadığı alanın geniş olması, literatürde kurumsal yapıyı temsilen çok farklı değişkenlerin kullanılmasına yol açmaktadır. Çalışmada ülkelerin kurumsal yapısını temsilen modelde yer alan ve temel bağımsız değişken olan kurumsal kalite indeksi, literatürde kurumsal yapı göstergesi olarak sıklıkla kullanılan (Shafique ve Haq 2006, Aradhyula vd. 2007, Chong ve Gradstein 2007, Chansukree 2012, Perera ve Lee 2013, Hartmann vd. 2015, Khosroabadi vd. 2015, Anyanwu vd. 2016, Afesorgbor ve Mahadevan 2016) beş değişkenin (Hükümet İstikrarı, Yolsuzluk, Hukuk ve Düzen, İçsel Çatışmalar ve Demokratik Hesap Verilebilirlik) bileşiminden oluşmaktadır. Bu beş değişkenin literatürde sıklıkla kullanılmasının temel nedeni; her birinin kültürün bir parçası, bir düşünce alışkanlığı ve oyunun kuralları olarak görülüyor olmasıdır. Bu değişkenlere ait veriler ICRG (International Country Risk Guide- Uluslararası Ülke Risk Rehberi) tarafından yayımlanan Politik Risk Bileşenleri (Political Risk Components) veri setinden elde edilmiştir. Bu beş değişkenin basit toplamı şeklinde hesaplanan kurumsal kalite indeksi, maksimum 42, minimum 0 değerini almaktadır. Yüksek değerler daha güçlü bir kurumsal yapı, düşük değerler ise daha zayıf bir kurumsal yapı anlamına gelmektedir ${ }^{13}$. Çalışmada ayrıca, ihmal edilmiş değişken sapmasına yol açmamak için iki tane de kontrol değişkeni kullanılmıştır. Bunlardan birincisi finansal gelişmişlik indeksi diğeri ise kişi başına reel gelirdir. Finansal gelişmişlik indeksi IMF (International Monetary Fund)'nin International Financial Statistics veri tabanından, kişi başına reel gelir ise Dünya Bankası Dünya Gelişme Göstergeleri çevrimiçi veri tabanından (World Bank World Development Indicators Online Database) elde edilmiştir.

\footnotetext{
${ }^{11}$ Avustralya, Avusturya, Belçika, Kanada, Şili, Kıbrıs Danimarka, Finlandiya, Fransa, Yunanistan, Hong Kong, Macaristan, İrlanda, İsrail, İtalya, Japonya, Lüksemburg, Hollanda, Yeni Zelenda, Norveç, Polonya, Portekiz, Singapur, İspanya, İsveç, İsviçre, Birleşik Krallık, Amerika Birleşik Devletleri, Uruguay.

12 Türkiye, Brezilya, Çin, Kolombiya, Kosta Rika Fildişi Sahili, Dominik Cumhuriyeti, Ekvator Mısır, Guatemala, Honduras, İran, Ürdün, Malezya, Meksika, Fas, Panama, Peru, Tunus, Zambiya, Filipinler, Arjantin, Venezuela, Güney Afrika.

${ }^{13} \mathrm{Ham}$ veriler incelendiğinde çalışmanın analizinde yer alan gelişmiş ülkelerin, gelişmekte olan ülkelere göre daha güçlü kurumsal yapıya sahip oldukları görülmektedir. Zira gelişmiş ülkelerde kurumsal kalite indeksinin ortalaması 33.4, gelişmekte olan ülkelerde ise $25.6^{\prime}$ dır.
} 


\subsection{Yatay Kesit Bağımlılık ve Homojenlik Analizi}

Panel veri modelinde yer alan her bir birim için hesaplanan hata terimleri arasında ilişki olması durumuna "yatay kesit bağımlılık" denir (Tatoğlu, 2013a: 9). Chudik ve Pesaran'a (2013) göre yatay kesit bağımlılığına yol açan iki temel etken söz konusudur. Bunlardan birincisi mekânsal ve ortak etkilerin ihmal edilmesi, ikinci ise birimler arasındaki sosyal, siyasi ve iktisadi ilişkilerin göz ardı edilmesidir. Bu sebeplerden dolayı ortaya çıkan yatay kesit bağımlıı̆ı̆ın dikkate alınmaması yani birinci nesil testler ile analiz yapılması, yapılan çıkarımların yanıltıcı olmasına, hatta parametrelerin tutarsız olmasına neden olabilmektedir (Chudik ve Pesaran, 2013: 2). Bundan dolayı ampirik analiz kısmında, ilk olarak değişkenler ve model bazında yatay kesit bağımlıı̆̆ı olup olmadığı, Breusch-Pagan (1980) tarafından geliştirilen LM testi, Pesaran (2004) tarafından geliştirilen $C D_{\llcorner\mathrm{M}}$ ve $\mathrm{CD}$ testleri ile araştırılmıştır. Her üç testinde yokluk ve alternatif hipotezleri aşağıdaki gibidir:

$H_{0}$ : Yatay Kesit Bağımlılık Yoktur.

$H_{1}$ : Yatay Kesit Bağımlıık Vardır.

Yatay kesit bağımlıığının yanı sıra modelde yer alan eğim katsayılarının homojenliği de araştırılmalıdır. Çoğu ampirik çalışmada, eğim katsayılarının homojen olduğu varsayılmaktadır. Ancak bu ön varsayımın gerçeği yansıtmaması durumunda ülkelerin-firmaların vb. kendine özgü karakterleri modele dâhil edilmemiş olacaktır. Bu ise elde edilen bulgulara duyulan güveni azaltacaktır (Pesaran ve Yamagata, 2008: 50; Nazlıoğlu vd., 2011: 6618). Bu nedenle, değişkenler arasında uzun dönemli ilişki araştırılamadan önce, sağııkı bulgular elde etmek adına eşbütünleşme denkleminde yer alan eğim katsayısının homojen mi yoksa heterojen mi olduğu belirlenmelidir.

Bu çalışmada, eğim katsayısının homojenliği, kullanılacak olan modellerin $\mathrm{N}$ ve T yapısı dikkate alınarak, Pesaran ve Yamagata (2008) tarafından geliştirilen homojenlik testi (Slope Homogeneity Test) ile araştırımıştır. Bu test, Swamy'in 1970 yılında yapmış olduğu çalışmadan faydalanılarak geliştirilmiş ve içerisinde biri Swamy istatistiğine dayanan $(\tilde{\Delta})$, diğeri ise Swamy istatistiğinin düzeltilmiş hali olan $\left(\tilde{\Delta}_{a d j}\right)$ iki test istatistiği barındırmaktadır. Her iki test istatistiğinde de $H_{0}: B_{i}=B$ yani eğim katsayının homojen olduğu yokluk hipotezi sınanmaktadır (Pesaran ve Yamagata, 2008: 50-57).

\subsection{Birim Kök Analizi}

Panel veri modelleri kesit boyutunun yanında bir de zaman boyutuna sahiptir. Özellikle makro panellerde zaman boyutunun geniş olması, durağanlık analizin yapılmasını zorunlu kılmaktadır. Durağan olmayan serilerin varyansı, gözlem sayısı sonsuza giderken, sonsuza yaklaşması nedeniyle, ekonomik ilişkilerin irdelenmesinde klasik panel yöntemler kullanılamaz. Kullanılması durumunda hem test istatistiklerine dayanan çözümlemeler güvenirliğini yitirir hem de sahte regresyon problemiyle karşı karşıya kalınabilir (Granger ve Newbold, 1974). Ayrıca, seri durağan değilse, davranışı sadece ele alınan dönem için incelenebilir ve diğer zaman dilimlerini de kapsayacak genellemeler yapılamaz (Gujarati ve Porter, 2012: 741). Son olarak, modelde yer alan değişkenler arasında uzun dönemli bir ilişkinin araştırılabilmesi için değişkenlerin aynı düzeyde bütünleşik olması gerekmektedir. Bu da yine durağanlık analizinin yapılmasını gerektirmektedir.

Bu nedenle ampirik analizin ikinci aşamasında, değişkenlerin durağanlık özellikleri incelenmiştir. Bunun için uygun boyut ve güce sahip CADF (Cross Sectionally Augmented Dickey Fuller) 
ve Smith vd. bootstrap birim kök testleri kullanılmıştır. Her iki test de yatay kesit bağımlılığı dikkate alan ikinci nesil testlerdir. CADF testi Pesaran (2007) tarafından geliştirilmiştir. Bu testin en önemli özelliği hem $\mathrm{N}>\mathrm{T}$ hem de $\mathrm{T}>\mathrm{N}$ iken güvenilir sonuçlar vermesidir. Ayrıca heterojenliği dikkate aldığından, her bir yatay kesit için ayrı ayrı sonuçlar üretmektedir. CADF birim kök testinde hipotezler şu şekildedir:

$H_{0}: b_{i}=0$ tüm i'ler (ülkeler) için seri durağan değildir.

$H_{1}: b_{i}<0, i=1,2 \ldots, N 1, b_{i}=0, i=N 1+1, N 1+2, N$ serilerin bazıları durağandır.

Pesaran, kesitler için hesaplanmış CADF test istatistiklerinin basit aritmetik ortalamasını, yatay kesitsel olarak genişletilmiş IPS (Cross-sectionally augmented IPS (CIPS)) test istatistiği olarak ifade etmekte ve bu testi panel veri serisinin durağanlık özelliklerini incelemede kullanmaktadır. CIPS istatistiği standart normal dağılım göstermediğinden kritik değerler Pesaran (2007) tarafından simülasyon yoluyla elde edilmiş ve tablolaştırılmıştır (Pesaran, 2007:267-269; Gengenbach vd., 2009: 5-6).

Çalışmada kullanılan bir diğer birim kök testi ise Smith vd. bootstrap panel birim kök testidir. Bu birim kök testi kendi içerisinde $\bar{t}, \overline{\mathrm{Max}}, \overline{L M}, \overline{M i n}, \overline{W S}$ olmak üzere beş farklı test istatistiği barındırmaktadır. İlgili testin $\mathrm{H}_{0}$ hipotezi tüm seriler durağan değildir biçimindeyken, $\mathrm{H}_{1}$ hipotezi en az bir serinin durağan olduğunu iddia etmektedir (Smith vd., 2004: 148).

\subsection{Eşbütünleşme Analizi}

Çalışmanın ampirik analizinin üçüncü aşamasında, değişkenler arasında uzun dönemli bir ilişkinin var olup olmadığı yatay kesit bağımlılı̆ını dikkate alan Durbin-Hausman ve LM Bootstrap eşbütünleşme testleri ile araştırılmıştır. Durbin-Hausman testi Westerlund (2008) tarafından geliştirilmiştir. Bu test, diğer eşbütünleşme testlerinin aksine bağımsız değişkenlerin aynı dereceden bütünleşik olmasını zorunlu kılmamaktadır. Bu kapsamda bağımsız değişkenlerin bazılarının I(0) bazılarının I(1) olması durumunda bile bu test kulllanılabilirdir. Ancak bu testin kullanılabilmesi için bağımlı değişkenin durağan olmaması gerekir (Westerlund, 2008: 205). Bu test kendi içerisinde, biri “Durbin-Hausman Grup-DHg" diğeri ise "Durbirn-Hausman Panel-DHp" olmak üzere iki istatistik barındırmaktadır. Bunlardan ilki yani Durbin Hausman grup istatistiği otoregresif parametrenin heterojen olduğunu varsayar ve bu varsayım altında eşbütünleşme ilişkisini inceler. Durbin Hausman grup istatistiği için yokluk ve alternatif hipotezler şu şekildedir:

$H_{0}: \phi_{i}=1$ i=1...N tüm i'ler için eşbütünleşme ilişkisi yoktur.

$H_{1}: \phi<1$ bazı i'ler için eşbütünleşme ilişkisi vardır.

Durbin Hausman panel istatistiği ise otoregresif parametrelerin homojen olduğunu varsayar ve bu varsayım altında eşbütünleşme ilişkisini inceler. Durbin Hausman panel istatistiği için yokluk ve alternatif hipotezler şu şekildedir:

$H_{0}: \phi_{i}=1 \quad i=1 \ldots N$ tüm i'ler için eşbütünleşme ilişkisi yoktur.

$H_{1}: \phi_{i}=\phi$ ve $\phi<1 \quad i=1 \ldots N$ tüm i'ler için eşbütünleşme ilişkisi vardır

Çalışmada kullanılacak olan bir diğer eşbütünleşme testi, Westerlund ve Edgerton (2007) tarafından geliştirilen LM Bootstrap testidir. Bu test McCoskey ve Kao (1998) tarafından geliştirilen Lanrange Çarpanı testine dayanmaktadır. Bu test kendi içerisinde iki test istatistiği barındırmaktadır. Bunlardan birincisi McCoskey and Kao (1998) tarafından önerilen ve standart nor- 
mal dağılıma sahip LMasymp istatistiği, diğer ise Westerlund ve Edgerton (2007) tarafından öne-

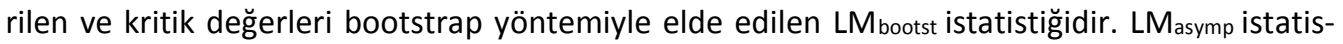
tiğinde hem kesit içinde hem de kesitler arasında korelasyon olmadığı varsayılmakteyken, LMbootst istatistiği hem kesit içindeki hem de kesitler arasındaki korelasyonu dikkate almaktadır. Her iki test istatistiği içinde yokluk ve alternatif hipotezler şu şekildedir:

$$
\begin{aligned}
& H_{0}: \sigma_{i}^{2}=0 \quad i=1 . . . N \text { tüm i'ler için eşbütünleşme ilişkisi vardır. } \\
& H_{1}: \sigma_{i}^{2}>1 \quad \text { bazı i'ler için eşbütünleşme ilişkisi yoktur }
\end{aligned}
$$

Dolayısıyla yokluk hipotezinin kabulü, örneklemde yer alan kesitlerin tamamında eşbütünleşme ilişkisinin var olduğunu göstermektedir (Westerlund ve Edgerton, 2007: 185-186).

\subsection{Katsayı Analizi}

Modelde yer alan değişkenler arasında eşbütünleşme ilişkinin tespit edilmesinden sonraki adım, uzun dönemli katsayıların tahmin edilmesidir. Çalışmada tam logaritmik doğrusal modelin katsayıları Pesaran (2006) tarafından geliştirilen CCE (Common Correlated Effects -Ortak illişkili Etkiler) ile tahmin edilmiştir. CCE tahmincisini diğer tahmincilerden ayıran en önemli özelliği hem yatay kesit bağımlıı̆̆ını hem de heterojenliği dikkate almasıdır. CCE yöntemi aşağıdaki heterojen panel veri regresyon modeline dayanmaktadır:

$$
y_{i t}=\alpha_{i}^{\prime} d_{t}+\beta_{i}^{\prime} x_{i t}+e_{i t}
$$

Burada $y_{i t}$ bağımlı değişkeni, $\mathbf{x}_{\mathbf{i t},}, K x 1$ boyutlu parametreler vektörünü, $\mathbf{d}_{\mathrm{t}} \mathrm{n} x 1$ boyutlu gözlenebilen (sabit, trend, mevsimsel kuklalar) etkiler vektörünü temsil etmektedir. $\mathbf{e}_{\text {it }}$ ise hata terimini temsil etmektedir. Pesaran (2006) yukarıda 3 nolu denklemde yer alan modelin tahmini için iki tane tahminci geliştirmiştir. Bunlar sırasıyla CCEMG (CCE Mean Group) ve CCEP (CCE Pooled) tahmincileridir. CCEMG tahmincisinde eğim parametrelerinin kesitten kesite değiştiği yani heterojen oldukları, CCEP tahmincisinde ise eğim parametrelerinin tüm kesitler için aynı olduğu yani homojen oldukları varsayılmaktadır (Pesaran, 2006; Kapetanios vd. 2010; Sadorsky, 2013: 55). Tam logaritmik doğrusal modelin katsayılarının tahmini için ayrıca Pedroni (2000) tarafından geliştirilen FMOLS (Fully Modified Ordinary Least Squares-Tam Değiştirilmiş En Küçük Kareler) tahminicisi de kullanılmıştır. Bunun temel sebebi ise olası otokorelasyon ve değişen varyans sorunlarından kaynaklı sapmaları düzeltmek ve daha tutarlı tahminciler elde etmektir.

Çalışmada dinamik tam logaritmik doğrusal modelin katsayıları ise Arellano ve Bover (1995) ve Blundell ve Bond (1998) tarafından geliştirilen Sistem GMM (Generalized Method of Moments- Genelleştirilmiş Momentler Metodu) ile tahmin edilmiştir. Dinamik modellerde bağımlı değişkenin gecikmeli değerinin bağımsız değişken olarak modelde yer alması içsellik problemine yol açacağından, bu modellerin tahmininde bilindik tahminciler (EKK) kullanılamamaktadır. Panel veri modellerinde $\mathrm{Git}_{\text {'t }}$ nin $\mu_{i}$ 'nün bir fonksiyonu olması, Git-1'nin de $\mu_{i}$ 'nün bir fonksiyonu olduğu anlamına gelmektedir. Hata terimi $\left(\varepsilon_{i t}=\mu_{i+} u_{i t}\right)$ ise içerisinde $\mu_{i}{ }^{\prime}$ yi barındırdığından, $\mathrm{G}_{\mathrm{it}-1}$ ile korelasyonlu olmakta ve katı dışsallık varsayımı bozulmaktadır. Dinamik modellerin bilindik yöntemlerle tahmin edilmesinin önünde matematiksel bir problem olmasa da, katı dışsallık varsayımının ihlalinden dolayı elde edilecek parametreler tutarsız ve sapmalı olmaktadır (Baltagi, 2013:155-156). 


\section{Ampirik Sonuçlar}

\subsection{Değişken Bazında Yatay Kesit Bağımlılık Analizi Sonuçları}

Değişkenlerde yatay kesit bağımlılık olup olmadığı $L M, C D_{L M}$ ve $C D$ testleriyle araştırılmış; gelişmiş ülkeler için elde edilen bulgular Tablo 2 'de, gelişmekte olan ülkeler için elde edilen bulgular ise Tablo 3'de gösterilmiştir.

Tablo 2: Gelişmiş Ülkeler Için Yatay Kesit Bağımlılık Testi Sonuçları

\begin{tabular}{|c|c|c|c|c|}
\hline Değişkenler & G & I & $Y$ & FDI \\
\hline Testler & \multicolumn{2}{|c|}{ Sabitli Model } & & \\
\hline Breusch-Pagan LM & $\begin{array}{l}608.31 \\
(0.000)\end{array}$ & $\begin{array}{l}500.56 \\
(0.000)\end{array}$ & $\begin{array}{l}729.92 \\
(0.000)\end{array}$ & $\begin{array}{l}515.86 \\
(0.000)\end{array}$ \\
\hline Pesaran CDıM & $\begin{array}{l}7.10 \\
(0.000)\end{array}$ & $\begin{array}{l}3.31 \\
(0.000)\end{array}$ & $\begin{array}{l}11.36 \\
(0.000)\end{array}$ & $\begin{array}{l}3.85 \\
(0.000)\end{array}$ \\
\hline Pesaran CD & $\begin{array}{l}-2.75 \\
(0.003) \\
\end{array}$ & $\begin{array}{l}-2.56 \\
(0.005)\end{array}$ & $\begin{array}{l}-1.86 \\
(0.031)\end{array}$ & $\begin{array}{l}-2.72 \\
(0.000) \\
\end{array}$ \\
\hline \multicolumn{5}{|c|}{ Sabitli ve Trendli Model } \\
\hline Breusch-Pagan LM & $\begin{array}{l}610.70 \\
(0.000)\end{array}$ & $\begin{array}{c}541.79 \\
(0.000)\end{array}$ & $\begin{array}{l}752.57 \\
(0.000)\end{array}$ & $\begin{array}{l}548.51 \\
(0.000)\end{array}$ \\
\hline Pesaran $\mathrm{CD}_{\mathrm{LM}}$ & $\begin{array}{l}7.18 \\
(0.000)\end{array}$ & $\begin{array}{l}4.76 \\
(0.000)\end{array}$ & $\begin{array}{l}12.16 \\
(0.000)\end{array}$ & $\begin{array}{l}5.00 \\
(0.000)\end{array}$ \\
\hline Pesaran CD & $\begin{array}{l}-2.31 \\
(0.010)\end{array}$ & $\begin{array}{l}-2.38 \\
(0.000)\end{array}$ & $\begin{array}{l}-1.74 \\
(0.040)\end{array}$ & $\begin{array}{l}-2.49 \\
(0.000)\end{array}$ \\
\hline
\end{tabular}

Tablo 3: Gelişmekte Olan Ülkeler Için Yatay Kesit Bağımlılık Testi Sonuçları

\begin{tabular}{lcccc}
\hline Değişkenler & G & I & Y & FDI \\
\hline Testler & \multicolumn{2}{c}{ Sabitli Model } & & 365.42 \\
& 325.92 & 552.91 & 449.92 & $(0.000)$ \\
Breusch-Pagan LM & $(0.021)$ & $(0.000)$ & $(0.000)$ & 3.76 \\
Pesaran CD LM & 2.12 & 11.78 & 7.37 & $(0.000)$ \\
Pesaran CD & $(0.017)$ & $(0.000)$ & $(0.000)$ & -2.74 \\
& -2.02 & -3.18 & -2.45 & $(0.003)$ \\
\hline & $(0.021)$ & $(0.000)$ & $(0.007)$ & 394.91 \\
\hline Breusch-Pagan LM & Sabitli ve Trendli Model & & $(0.000)$ \\
& 391.98 & 599.89 & 400.71 & 5.06 \\
Pesaran CD & $(0.000)$ & $(0.000)$ & $(0.000)$ & $(0.000)$ \\
& 4.93 & 13.78 & 5.30 & -2.69 \\
Pesaran CD & $(0.000)$ & $(0.000)$ & $(0.000)$ & $(0.004)$ \\
\hline Not: Maksimum gecikme uzunluğu 2 olarak alınmış olup, olasılık değerleri parantez içinde verilmiştir.
\end{tabular}

Tablo 2 ve 3'de yer alan test istatistikleri incelendiğinde her üç testtin de benzer sonuçlar ortaya koyduğu ve "değişkenler de yatay kesit bağımlılık yoktur" şeklindeki $\mathrm{H}_{0}$ hipotezinin, her iki ülke grubu içinde reddedildiği görülmektedir. Bu bulgu, hem gelişmiş hem de gelişmekte olan ülkeleri temsilen oluşturulan örneklemde yer alan ülkelerin herhangi birinde; ister zaman isterse de mekândan kaynaklı ortaya çıkacak bir krizin veya şokun örneklemde yer alan diğer ülkeleri de etkileyeceği anlamına gelmektedir. 


\subsection{Birim Kök Analizi Sonuçları}

Değişkenlerin tümünde yatay kesit bağımlılık tespit edildiğinden değişkenlerin durağanlık özellikleri CADF ve Smith vd. Boostrap gibi ikinci nesil birim kök testleri ile araştırılmıştır. Gelişmiş ülkeler için birim kök testi sonuçları aşağıda Tablo 4 ve 5'de, gelişmekte olan ülkeler için birim kök test sonuçları ise Tablo 6 ve 7'de gösterilmektedir.

Tablo 4: Gelişmiş Ülkeler Iç̧in CADF Birim Kök Testi Sonuçları

\begin{tabular}{ccccc}
\hline Model & Düzey (c) & Düzey $(\mathrm{c}+\mathrm{t})$ & Birinci Fark $(\mathrm{c})$ & Birinci Fark $(\mathrm{c}+\mathrm{t})$ \\
\hline Değişkenler & CIPS İstatistiği & CIPS İstatistiği & CIPS İstatistiği & CIPS İstatistiği \\
\hline \hline G & -2.11 & -1.92 & -2.82 & -3.03 \\
I & -2.49 & -2.73 & -4.62 & -4.67 \\
Y & -2.08 & -2.41 & -3.42 & -3.44 \\
FDI & -2.70 & -2.80 & -5.27 & -5.28 \\
\hline
\end{tabular}

Not: Birim kök testlerinde kullanılan modeller: "c+t, trend ve sabiti içerir"; "c, sadece sabiti içerir" şeklindedir. \%5 anlamlılık düzeyinde sabitli model için kritik değer -2.15, sabitli ve trendli model için ise kritik değer $-2.66^{\prime}$ dır. Maksimum gecikme uzunluğu 2 olarak alınmıştır.

Tablo 5: Gelişmiş Ülkeler İçin Smith vd. Bootstrap Testi Sonuçları

\begin{tabular}{|c|c|c|c|c|c|c|c|c|}
\hline \multicolumn{5}{|c|}{ Düzey (c) } & \multicolumn{4}{|c|}{ Birinci Fark (c) } \\
\hline & $\mathrm{G}$ & 1 & $Y$ & FDI & $\mathrm{G}$ & 1 & $Y$ & FDI \\
\hline \multirow[t]{2}{*}{ Ips } & -2.10 & -2.12 & -1.39 & -1.64 & -2.44 & -4.41 & -3.26 & -4.78 \\
\hline & $(0.005)$ & $(0.006)$ & $(0.610)$ & $(0.322)$ & $(0.000)$ & $(0.000)$ & $(0.000)$ & $(0.000)$ \\
\hline \multirow[t]{2}{*}{ Max } & -0.28 & -1.33 & 0.42 & -.0 .27 & -1.96 & -4.16 & -3.02 & -4.53 \\
\hline & $(0.986)$ & $(0.095)$ & (0.999) & $(0.987)$ & $(0.000)$ & $(0.000)$ & $(0.000)$ & $(0.000)$ \\
\hline \multirow[t]{2}{*}{ MinLM } & 2.91 & 2.88 & 1.01 & 0.74 & 4.21 & 11.22 & 7.47 & 12.04 \\
\hline & $(0.001)$ & $(0.015)$ & $(0.916)$ & $(0.986)$ & $(0.000)$ & $(0.000)$ & $(0.000)$ & $(0.000)$ \\
\hline \multirow[t]{2}{*}{ WS } & -0.75 & -1.60 & 0.328 & -0.64 & -2.22 & -4.44 & -3.28 & -4.80 \\
\hline & $(0.937)$ & $(0.041)$ & $(1.000)$ & $(0.941)$ & $(0.000)$ & $(0.000)$ & $(0.000)$ & $(0.000)$ \\
\hline \multicolumn{5}{|c|}{ Düzey $(\mathrm{c}+\mathrm{t})$} & \multicolumn{4}{|c|}{ Birinci Fark $(c+t)$} \\
\hline & $\mathrm{G}$ & 1 & $Y$ & FDI & $\mathrm{G}$ & 1 & $Y$ & FDI \\
\hline \multirow[t]{2}{*}{ Ips } & -2.04 & -2.31 & -1.68 & -1.39 & -2.82 & -4.56 & -3.45 & -5.01 \\
\hline & $(0.626)$ & $(0.248)$ & $(0.885)$ & $(0.985)$ & $(0.002)$ & $(0.000)$ & $(0.000)$ & $(0.000)$ \\
\hline \multirow[t]{2}{*}{ Max } & -1.22 & -1.79 & -1.31 & -1.25 & -2.49 & -4.30 & -3.32 & -4.70 \\
\hline & $(0.947)$ & $(0.500)$ & $(0.868)$ & $(0.958)$ & $(0.000)$ & $(0.000)$ & $(0.000)$ & $(0.000)$ \\
\hline \multirow[t]{2}{*}{ MinLM } & 3.20 & 3.95 & 2.56 & 2.12 & 5.96 & 11.96 & 8.65 & 12.75 \\
\hline & $(0.728)$ & $(0.360)$ & $0.877)$ & $(0.973)$ & $(0.000)$ & $(0.000)$ & $(0.000)$ & $(0.000)$ \\
\hline \multirow[t]{2}{*}{ WS } & $-1.74)$ & -2.13 & -1.64 & -1.65 & -2.81 & -4.69 & -3.66 & -5.10 \\
\hline & $(0.956)$ & $(0.472)$ & $(0.925)$ & $(0.942)$ & $(0.000)$ & $(0.000)$ & $(0.000)$ & $(0.000)$ \\
\hline
\end{tabular}

Not: Birim kök testlerinde kullanılan modeller: "c+t, trend ve sabiti içerir"; "c, sadece sabiti içerir" şeklindedir. Maksimum gecikme uzunluğu 2 olarak alınmış olup, olasılık değerleri 5.000 bootstrap dağılımından elde edilmiş ve parantez içinde gösterilmiştir.

Gelişmiş ülkeler için CADF testi sonuçları incelendiğinde; Gini katsayısı ve reel kişi başına gelir değişkenlerinin hem sabitli hem de sabitli ve trendli modelde fark durağan oldukları, kurumsal kalite ve finansal gelişmişlik değişkenlerinin ise hem sabitli hem de sabitli trendli modelde seviyede durağan oldukları görülmektedir. Gelişmiş ülkeler için Smith vd. Boostrap testi sonuçları incelendiğinde ise CADF testinden farklı olarak finansal gelişmişlik değişkenin seviyede, hem sabitli hem de sabitli ve trendli modelde durağan olmadığı, birinci farkı alındığında ise durağanlaştığı görülmektedir. Yine CADF testi sonuçlarından farklı olarak kurumsal kalite değişkenin seviyede, trendli ve sabitli modelde durağan olmadığı, birinci farkı alındığında ise durağanlaştığı görülmektedir. 
Tablo 6: Gelişmekte Olan Ülkeler İçin CADF Birim Kök Testi Sonuçları

\begin{tabular}{lcccc}
\hline Model & Düzey(c) & Düzey (c+t) & Birinci Fark (c) & Birinci Fark (c+t) \\
\hline Değişkenler & CIPS İstatistiği & CIPS İstatistiği & CIPS İstatistiği & CIPS İstatistiği \\
\hline \hline G & -0.949 & -1.91 & -2.56 & -2.77 \\
I & -2.29 & -2.73 & -4.73 & -4.88 \\
Y & -2.18 & -2.59 & -4.11 & -4.31 \\
FDI & -2.71 & -2.63 & -4.78 & -4.89 \\
\hline
\end{tabular}

Not: Birim kök testlerinde kullanılan modeller: "c+t, trend ve sabiti içerir"; "c, sadece sabiti içerir" şeklindedir. \%5 anlamlılık düzeyinde sabitli model için kritik değer -2.20, sabitli ve trendli model için ise kritik değer -2.72' dir. Maksimum gecikme uzunluğu 2 olarak alınmıştır.

Tablo 7: Gelişmekte Olan Ülkeler İçin Smith vd. Bootstrap Testi Sonuçları

\begin{tabular}{|c|c|c|c|c|c|c|c|c|}
\hline \multicolumn{5}{|c|}{ Düzey (c) } & \multicolumn{3}{|c|}{ Birinci Fark (c) } & \multirow[b]{2}{*}{ FDI } \\
\hline & G & $\mathrm{I}$ & $\mathrm{Y}$ & FDI & G & 1 & $Y$ & \\
\hline Ips & $\begin{array}{l}-0.46 \\
(0.999)\end{array}$ & $\begin{array}{l}-2.32 \\
(0.002)\end{array}$ & $\begin{array}{l}-0.18 \\
(1.000)\end{array}$ & $\begin{array}{l}-1.44 \\
(0.594)\end{array}$ & $\begin{array}{l}-1.94 \\
(0.023)\end{array}$ & $\begin{array}{l}-4.62 \\
(0.000)\end{array}$ & $\begin{array}{l}-3.88 \\
(0.000)\end{array}$ & $\begin{array}{l}-5.44 \\
(0.000)\end{array}$ \\
\hline Max & $\begin{array}{l}-0.11 \\
(0.989)\end{array}$ & $\begin{array}{l}-1.41 \\
(0.050)\end{array}$ & $\begin{array}{l}0.21 \\
(1.000)\end{array}$ & $\begin{array}{l}-0.71 \\
(0.898)\end{array}$ & $\begin{array}{l}-1.71 \\
(0.000)\end{array}$ & $\begin{array}{l}-4.51 \\
(0.000)\end{array}$ & $\begin{array}{l}-3.42 \\
(0.000)\end{array}$ & $\begin{array}{l}-5.12 \\
(0.000)\end{array}$ \\
\hline MinLM & $\begin{array}{l}2.78 \\
(0.028)\end{array}$ & $\begin{array}{l}2.80 \\
(0.024)\end{array}$ & $\begin{array}{l}1.63 \\
(0.638)\end{array}$ & $\begin{array}{l}1.57 \\
(0.674)\end{array}$ & $\begin{array}{l}3.50 \\
(0.000)\end{array}$ & $\begin{array}{l}12.17 \\
(0.000)\end{array}$ & $\begin{array}{l}8.96 \\
(0.000)\end{array}$ & $\begin{array}{l}13.88 \\
(0.000)\end{array}$ \\
\hline WS & $\begin{array}{l}-0.85 \\
(0.812)\end{array}$ & $\begin{array}{l}-1.64 \\
(0.036)\end{array}$ & $\begin{array}{l}0.04 \\
(1.000)\end{array}$ & $\begin{array}{l}-0.73 \\
(0.968)\end{array}$ & $\begin{array}{l}-1.97 \\
(0.000)\end{array}$ & $\begin{array}{l}-4.78 \\
(0.000)\end{array}$ & $\begin{array}{l}-3.69 \\
(0.000)\end{array}$ & $\begin{array}{l}-5.41 \\
(0.000)\end{array}$ \\
\hline Düz & $c+t)$ & & & & Birir & $\operatorname{ark}(\mathrm{c}+\mathrm{t})$ & & \\
\hline & $\mathrm{G}$ & $\mathrm{I}$ & $\mathrm{Y}$ & FDI & $\mathrm{G}$ & 1 & $Y$ & FDI \\
\hline Ips & $\begin{array}{l}-1.38 \\
(0.990)\end{array}$ & $\begin{array}{l}-2.35 \\
(0.212)\end{array}$ & $\begin{array}{l}-1.97 \\
(0.691)\end{array}$ & $\begin{array}{l}-2.53 \\
(0.047)\end{array}$ & $\begin{array}{l}-2.45 \\
(0.095)\end{array}$ & $\begin{array}{l}-5.00 \\
(0.000)\end{array}$ & $\begin{array}{l}-4.09 \\
(0.000)\end{array}$ & $\begin{array}{l}-5.57 \\
(0.000)\end{array}$ \\
\hline Max & $\begin{array}{l}-0.89 \\
(0.988)\end{array}$ & $\begin{array}{l}-1.85 \\
(0.360)\end{array}$ & $\begin{array}{l}-1.29 \\
(0.912)\end{array}$ & $\begin{array}{l}-1.79 \\
(0.483)\end{array}$ & $\begin{array}{l}-2.23 \\
(0.015)\end{array}$ & $\begin{array}{l}-4.73 \\
(0.000)\end{array}$ & $\begin{array}{l}-3.70 \\
(0.000)\end{array}$ & $\begin{array}{l}-5.30 \\
(0.000)\end{array}$ \\
\hline MinLM & $\begin{array}{l}2.52 \\
(0.921)\end{array}$ & $\begin{array}{l}3.81 \\
(0.421)\end{array}$ & $\begin{array}{l}2.79 \\
(0.880)\end{array}$ & $\begin{array}{l}3.64 \\
(0.542)\end{array}$ & $\begin{array}{l}5.07 \\
(0.015)\end{array}$ & $\begin{array}{l}13.05 \\
(0.000)\end{array}$ & $\begin{array}{l}10.09 \\
(0.000)\end{array}$ & $\begin{array}{l}14.58 \\
(0.000)\end{array}$ \\
\hline WS & $\begin{array}{l}-1.50 \\
(0.995)\end{array}$ & $\begin{array}{l}-2.09 \\
(0.520)\end{array}$ & $\begin{array}{l}-1.75 \\
(0.929)\end{array}$ & $\begin{array}{l}-2.13 \\
(0.451)\end{array}$ & $\begin{array}{l}-2.58 \\
(0.011)\end{array}$ & $\begin{array}{l}-5.16 \\
(0.000)\end{array}$ & $\begin{array}{l}-4.10 \\
(0.000)\end{array}$ & $\begin{array}{l}-5.71 \\
(0.000)\end{array}$ \\
\hline
\end{tabular}

Not: Birim kök testlerinde kullanılan modeller: "c+t, trend ve sabiti içerir"; "c, sadece sabiti içerir" şeklindedir. Maksimum gecikme uzunluğu 2 olarak alınmış olup, olasılık değerleri 5.000 bootstrap dağılımından elde edilmiş ve parantez içinde gösterilmiştir.

Gelişmekte olan ülkeler için gerçekleştirilen iki birim kök testi sonucu incelendiğinde; elde edilen bulguların gelişmiş ülkeler için elde edilen bulgularla aynı oldukları görülmektedir. Panel veri analizi kapsamında gerçekleştirilen durağanlık sınamalarının çok net olmayan bulgular ortaya koyması literatürde sıklıkla karşılaşılan bir durumdur. Böyle durumlarda genellikle test istatistiklerinin çoğunluğunun hangi yönü gösterdiği dikkate alınmaktadır (Baltagi; 2013:277286). Buna istinaden hem gelişmiş hem de gelişmekte olan ülkeler için Gini katsayısının, reel kişi başına gelir ve finansal gelişmişlik indeksi değişkenlerinin birinci dereceden eşbütünleşik I(1) olduğu, kurumsal kalite değişkenin ise seviyede durağan I(0) durağan olduğu sonucuna varılmıştır.

\subsection{Homojenlik ve Model Bazında Yatay Kesit Bağımlııık Analizi Sonuçları}

Gelişmiş ve gelişmekte olan ülkelerde kurumsal kalitenin gelir dağılımı üzerindeki etkisini araştırmak amacıyla kurulan modellerin (1 ve 2 nolu) parametrelerinin homojen mi yoksa heterojen mi olduğu Slope Homogeneity testi ile modellerde yatay kesit bağımlılık olup olmadığı ise LM, CDım ve CD testleriyle araştırılmış ve sonuçlar aşağıda Tablo 8'de sunulmuştur. 
Eskişehir Osmangazi Üniversitesi ïBF Dergisi

Tablo 8: Modelde Yatay Kesit Bağımlılık ve Homojenlik Testi Sonuçları

\begin{tabular}{lcc}
\hline Testler & Gelişmiş Ülkeler & Gelişmekte Olan Ülkeler \\
\hline \hline Breusch-Pagan LM & 1416.77 & 1168.11 \\
& $(0.000)$ & $(0.000)$ \\
Pesaran CD & 35.47 & 37.97 \\
& $(0.000)$ & $(0.000)$ \\
Pesaran CD & 5.28 & 13.09 \\
& $(0.000)$ & $(0.000)$ \\
\hline \hline Delta Tilde & 38.14 & 29.02 \\
& $(0.000)$ & $(0.000)$ \\
Delta Tilde Adj & 40.37 & 30.71 \\
& $(0.000)$ & $(0.000)$ \\
\hline Not: Olasılık değerleri parantez içinde gösterilmektedir. & & \\
\hline
\end{tabular}

Tablo 8'de yer alan homojenlik testinin sonuçları incelendiğinde; her iki test istatistiğine göre de "otoregresif parametreler homojendir" şeklindeki $\mathrm{H}_{0}$ hipotezi reddedilmektedir. Bu bulgu, gelişmiş ve gelişmekte olan ülkeleri temsilen oluşturulan örneklemlerde yer alan ülkelerde, kurumsal kalite ile gelir dağılımı arasındaki ilişkinin farklılık gösterdiği anlamına gelmektedir. Tablo 8'de yer alan yatay kesit bağımlılık testlerinin sonuçları incelendiğinde ise her üç testtin de benzer sonuçlar ortaya koyduğu ve "modelde yatay kesit bağımlılık yoktur" şeklindeki $\mathrm{H}_{0}$ hipotezinin her iki ülke grubu için de reddedildiği görülmektedir.

\subsection{Homojenlik ve Model Bazında Yatay Kesit Bağımlılık Analizi Sonuçları}

Modellerde yatay kesit bağımlılık bulunduğundan, eğim katsayıları heterojen olduğundan ve modellerde yer alan bazı açıklayıcı değişkenler durağan olduğundan, değişkenler arasındaki uzun dönemli bir ilişkinin varlığı Durbin-Hausman ve LM Bootstrap eşbütünleşme testleri ile araştırılmıştır. Elde edilen bulgular aşağıda Tablo 9'da gösterilmektedir.

Tablo 9: Gelişmiş ve Gelişmekte Olan Ülkeler Için Eşbütünleşme Analizi Sonuçlar

\begin{tabular}{lllll}
\hline Testler & Gelişmiş Ülkeler & Gelişmekte Olan Ülkeler \\
\hline \hline Durbin Hausman & İstatistik & Olasılık & İstatistik & Olasılık \\
DH_g & -1.66 & 0.048 & -1.990 & 0.023 \\
LM Bootstrap & İstatistik & Olasılık & İstatistik & Olasılık \\
Bootstrap & 8.29 & 0.249 & 5.68 & 0.842 \\
\hline
\end{tabular}

Not: LM Bootstrap testinde olasılık değerleri 5.000 bootstrap dağılımından elde edilmiştir. Durbin Hausman testinde bant genişliği “bandwith”"Newey-West yöntemine göre seçilmiştir.

Tablo 9'da yer alan Durbin Hausman testi sonuçları incelendiğinde; "değişkenler arasında eşbütünleşme ilişkisi yoktur" şeklindeki $\mathrm{H}_{0}$ hipotezinin hem gelişmiş hem de gelişmekte olan ülkeler için \%5 anlamlılık düzeyinde reddedildiği görülmektedir. LM bootstrap testi sonuçlarına göre ise "değişkenler arasında eşbütünleşme ilişkisi vardır" şeklindeki $\mathrm{H}_{0}$ hipotezi, hem gelişmiş hem de gelişmekte olan ülkeler için \%5 anlamlılık düzeyinde kabul edilmektedir. Bu sonuçlara göre gelişmiş ve gelişmekte olan ülkelerde, bağımlı değişken Gini katsayısı ile bağımsız değişkenler kurumsal kalite, reel kişi başına gelir ve finansal gelişmişlik arasında uzun dönemli durağan bir ilişki söz konusudur.

\subsection{Katsayı Analizi Sonuçları}

Tam logaritmik doğrusal modelin katsayıları CCEMG ve FMOLS ile dinamik tam logaritmik doğrusal modelin katsayıları ise Sistem GMM ile tahmin edilmiştir. Gelişmiş ülkeler için elde edilen bulgular aşağıda Tablo $10^{\prime}$ da, gelişmekte olan ülkeler için elde edilen bulgular ise Tablo $11^{\prime}$ 'de gösterilmektedir. 
Tablo 10: Gelişmiş Ülkeler İçin Katsayı Tahminleri

\begin{tabular}{|c|c|c|c|}
\hline Değişkenler & CCEMG & FMOLS & SISTEM GMM \\
\hline G $\mathrm{G}(-1)$ & & & $\begin{array}{l}0.864^{* * *} \\
(0.000)\end{array}$ \\
\hline I & $\begin{array}{l}-0.034 * \\
(0.093)\end{array}$ & $\begin{array}{l}-0.051 * * * \\
(0.000)\end{array}$ & $\begin{array}{l}-0.005^{* * *} \\
(0.000)\end{array}$ \\
\hline Y & $\begin{array}{l}-0.119 * * * \\
(0.003)\end{array}$ & $\begin{array}{l}-0.093 * * * \\
(0.000)\end{array}$ & $\begin{array}{l}-0.003^{* * *} \\
(0.000)\end{array}$ \\
\hline FDI & $\begin{array}{l}-0.004 \\
(0.734)\end{array}$ & $\begin{array}{l}0.017^{* *} \\
(0.021)\end{array}$ & $\begin{array}{l}0.003^{* * *} \\
(0.000)\end{array}$ \\
\hline Sargan Testi & & & $(0.826)$ \\
\hline AR (2) Testi & & & (0.999) \\
\hline \multicolumn{4}{|c|}{$\begin{array}{l}\text { Not: } * * *, * *, * \text { sırasıyla } \% 1, \% 5 \text { ve } \% 10 \text { düzeyinde istatistiki anlamlılı̆ı göstermektedir. CCEMG tahmininde Newey- } \\
\text { West varyans-kovaryans tahmincisi kullanılmıştır. FMOLS testinde gecikme uzunluğu Schwarz bilgi kriterine göre } 1 \\
\text { olarak alınmıştır. Uzun dönem katsayı tahminlerinde Kernel Bartlett metodu kullanılmış ve bant genişliği Newey- } \\
\text { West yöntemiyle belirlenmiştir. AR (2) ve Sargan testlerine ve katsayılara ait olasılık değerleri parantez içerisinde } \\
\text { yer almaktadır. }\end{array}$} \\
\hline
\end{tabular}

Gelişmiş ülkelere yönelik tahminler incelendiğinde; her üç tahminciyle de elde edilen katsayıların çoğunlukla işaret açısından birbirleriyle tutarlı ve istatiksel olarak anlamlı oldukları görülmektedir. Bu kapsamda, kurumsal kalitedeki ve reel kişi başına gelirdeki bir artışın Gini katsayısını negatif etkilediği yani gelir dağılımı eşitsizliğini azalttığı, finansal gelişmedeki bir artışın ise Gini katsayısını pozitif etkilediği yani gelir dağılımı eşitsizliğini arttırdığı görülmektedir. Ayrıca, geçmiş gelir eşitsizliği düzeyinin mevcut gelir eşitsizliği düzeyini açıklamada çok önemli bir faktör olduğu anlaşılmaktadır. Son olarak Sistem GMM tahminine yönelik gerçekleştirilen Sargan ve Arellano-Bond otokorelasyon testlerinin sonuçları incelendiğinde sırasıyla "araç değişkenler geçerlidir" ve "ikinci dereceden otokorelasyon yoktur" şeklindeki $\mathrm{H}_{0}$ hipotezlerinin kabul edildiği görülmektedir.

Tablo 11: Gelişmekte Olan Ülkeler Için Katsayı Tahminleri

\begin{tabular}{|c|c|c|c|}
\hline Değişkenler & CCEMG & FMOLS & SISTEM GMM \\
\hline \multirow[t]{2}{*}{$G(-1)$} & & & $0.975 * * *$ \\
\hline & & & $(0.000)$ \\
\hline \multirow[t]{2}{*}{ I } & $0.032 * * *$ & $0.065^{* * *}$ & $0.003^{* * *}$ \\
\hline & $(0.009)$ & $(0.000)$ & $(0.000)$ \\
\hline \multirow[t]{2}{*}{$Y$} & $0.108^{* *}$ & $-0.116^{* * *}$ & $-0.008 * * *$ \\
\hline & $(0.024)$ & $(0.000)$ & $(0.000)$ \\
\hline \multirow[t]{2}{*}{ FDI } & 0.017 & $-0.027 * *$ & $-0.009 * * *$ \\
\hline & $(0.272)$ & $(0.015)$ & $(0.000)$ \\
\hline \multicolumn{2}{|l|}{ Sargan Testi } & & $(0.586)$ \\
\hline \multicolumn{2}{|l|}{ AR (2) Testi } & & $(0.851)$ \\
\hline \multicolumn{4}{|c|}{$\begin{array}{l}\text { Not: }{ }^{* *},{ }^{* *},{ }^{*} \text { sırasıyla } \% 1, \% 5 \text { ve } \% 10 \text { düzeyinde istatistiki anlamlılığı göstermektedir. CCEMG tahmininde Newey- } \\
\text { West varyans-kovaryans tahmincisi kullanılmıştır. FMOLS testinde gecikme uzunluğu Schwarz bilgi kriterine göre } 1 \\
\text { olarak alınmıştır. Uzun dönem katsayı tahminlerinde Kernel Bartlett metodu kullanılmıs ve bant genişliği Newey- } \\
\text { West yöntemiyle belirlenmiştir. AR(2) ve Sargan testlerine ve katsayılara ait olasılık değerleri parantez içerisinde yer } \\
\text { almaktadır. }\end{array}$} \\
\hline
\end{tabular}

Gelişmekte olan ülkeler için elde edilen katsayılar incelendiğinde; gelişmiş ülkelerin aksine kurumsal kalitedeki bir artışın Gini katsayısını pozitif etkilediği yani gelir dağııımı eşitsizliğini arttırdığı, finansal gelişmedeki bir artışın ise Gini katsayısını negatif etkilediği yani gelir dağılımı eşitsizliğini azalttığı görülmektedir. Reel kişi başına gelirdeki artışlar ise gelişmiş ülkelerde olduğu gibi gelişmekte olan ülkelerde de Gini katsayısını negatif etkilemekte yani gelir dağııımı eşitsizliğini azaltmaktadır. Gelişmiş ülkelerde olduğu gibi gelişmekte olan ülkelerde de her üç 
tahminci ile elde edilen katsayılar çoğunlukla işaret açısından birbirleri ile tutarlı ve istatiksel olarak anlamlıdırlar. Son olarak, Sistem GMM tahminine yönelik gerçekleştirilen Sargan ve Arellano-Bond otokorelasyon testlerinin sonuçları incelendiğinde sırasıyla "araç değişkenler geçerlidir" ve "ikinci dereceden otokorelasyon yoktur" şeklindeki $\mathrm{H}_{0}$ hipotezlerinin kabul edildiği görülmektedir.

\section{Sonuç ve Politika Önerileri}

Gelir dağılımı konusu Adam Smith'ten beri sistematik olarak ele alınıp incelenmektedir. Literatürün ilk evrelerinde üretim faktör sahipliğinin homojen bir dağılım göstermesi sebebiyle fonksiyonel gelir dağılımı ön plana çıkmakta ve incelenmekteyken, günümüzde gelir dağılımı dendiğinde ilk olarak akla kişisel gelir dağılımı gelmektedir. Kişisel gelir dağılımına yönelik ilgi her dönem değişiklik gösterse de özellikle 1980'den itibaren bu ilginin arttığı görülmektedir. Bunun temel sebebi ise son birkaç on yılda dünyadaki birçok ülkenin ekonomik büyüme ve gelir dağılımı konusunda ayrışmaya maruz kalmasıdır. Gelir dağılımı eşitsizliği ciddi bir sosyal sorun olarak görüldüğünden bu eşitsizliğinin nedenlerinin belirlenmesine yönelik çalışmalar da hızla artmaktadır. Bu çalışmaların birçoğu gelir dağıımı eşitsizliğini beşeri sermaye donanımı, yetenek, teknolojik ilerlemeler vb. faktörler ile açıklamaya çalışmaktadır. Bununla birlikte özellikle 2000 'li yıllardan itibaren kurumların gelir dağılımı üzerindeki etkisini inceleyen bir literatür de oluşmuştur.

Kurumların gelir dağılımı üzerindeki etkisi farklı kanallardan ortaya çıkabilmektedir. Bu kapsamda kurumlar, kişisel teşvikleri yönlendirerek, rant arama faaliyetlerini ve iktisadi ayrımcılığı sınırlandırarak, kayıt dışı istihdamı ve yeniden dağıtımı etkileyerek gelirin ülke içindeki dağılımını da etkiler. Kurumların gelir dağılımı üzerindeki etkisinin ülkelerin gelişmişlik düzeyine göre farklııık gösterebileceği düşüncesinden yola çıkarak bu çalışmada kurumların gelir dağılımı üzerindeki etkisi, gelişmiş ve gelişmekte olan ülkeler için ayrı ayrı incelenmiştir. Biri statik biri de dinamik olmak üzere iki farklı modelin kullanıldığı bu çalışmada, 1988-2014 dönemi kapsayan yıllık veriler kullanılmış olup, dengeli panel veri analizi tercih edilmiştir. Hem gelişmiş hem de gelişmekte olan ülkeler için yapılan analizler kapsamında elde edilen bulgular şöyledir:

i) Gelişmiş ülkelerde kurumsal kalitedeki bir artış gelir dağılımı eşitsizliğini azaltmaktadır. Bu bulgu kurumsal kaliteyi arttırmaya yönelik politikaların gelir dağılımı eşitsizliğini azaltmada önemli bir araç olabileceğine işaret etmektedir. Bundan dolayı, gelişmiş ülkelerde gelir dağııımı eşitsizliğini azaltmaya yönelik politikalar oluşturulurken, kurumsal faktörler de göz önünde bulundurmalı ve kurumsal kaliteyi arttıracak yapısal reformlar tasarlanmalıdır.

iii) Gelişmekte olan ülkelerde kurumsal kalitedeki bir artış gelir dağılımı eşitsizliğinin artmasına neden olmaktadır. Gelişmekte olan ülkeler için elde edilen bu bulgu; gelişmiş ülkeler için elde edilen bulgularla ve literatürdeki bazı çalışmaların ampirik bulgularıyla çelişiyor olsa da, gelişmekte olan ülkelerdeki bir dizi nedenden dolayı makuldür. Bu nedenler şöyle sıralanabilir:

İlk olarak gelişmekte olan ülkelerde kayıt dışı sektör oldukça büyüktür ${ }^{14}$. Kayıt dışı sektör özellikle toplumun en fakir insanlarına istihdam dolayısıyla gelir sağlamaktadır. Bu insanların birçoğu resmi işlerde çalışacak vasıflara sahip olmadıkları gibi ayrımcılık vb. unsurlarda resmi iş olanaklarını kısıtlamaktadır. Yolsuzluktaki bir azalma, hukukun üstünlügündeki bir artış vergi tahsilatındaki gelişmeler ve yeni vergiler gibi kurumsal kalitede artışa sebep olacak kurumsal

\footnotetext{
${ }^{14}$ Schneider (2010)'e göre gelişmekte olan ülkelerde toplam iş gücünün \%40 ile \%50 arasındaki bir bölümü kayıt dışı sektörde istihdam edilmektedir.
} 
reformlar bu ülkelerde işlerin daha resmi hale gelmesine yol açmaktadır. Bu ise kayıt dışı ekonominin faaliyet gösterdiği sistemi zayıflatarak kayıt dışı sektörde operasyonel maliyetlerin artmasına, karların ve istihdamın ise azalmasına neden olmaktadır. Bu süreç, kayıt dışı sektörlerde faaliyet gösteren düşük gelirli bireylerin gelirlerinin mutlak ve görece azalmasına, resmi sektörlerde faaliyet gösterenlerin kazançlarının ise mutlak ve görece artmasına neden olmakta ve gelir dağılımı eşitsizliği artmaktadır. İkinci olarak, yolsuzluk bu ülkelerde gelir dağılımı eşitsizliğini azaltmanın fiyatı olarak görülebilmektedir. Zira özellikle gelişmekte olan ülkelerde düşük gelirlilerin refahlarını iyileştirmeye yönelik büyük kamu projeleri beraberinde yolsuzluğu teşvik edebilmektedir. Politika yapıcıları bunun farkında olsalar dahi düşük gelirlilerin refah düzeyini arttırmak istemlerinden dolayı böyle programları çoğu kez uygulamaya koymaktadırlar. Bu ise bir yandan yolsuzluğun artmasına bir yandan da gelir dağılımı eşitsizliğini azalmasına neden olabilmektedir ${ }^{15}$. Üçüncü ve ayrıntılı araştırmayı hak eden bir diğer neden ise gelişmekte olan ülkelerde görülen yolsuzluğun "gelişimsel" türde olma ihtimalidir. Gelişimsel yolsuzlukta kamu görevlilerinin kazancı özel sektör kârlarının boyutuna ve büyümesine bağlı olduğundan, kamu görevlileri genellikle ekonomik büyümeyi arttıran politikaların uygulanmasını sağlamaktadır. Bu politikalar sonrası ortaya çıkan iktisadi büyüme, gelir dağılımı eşitsizliğinin azalmasına yardımcı olurken yolsuzluk ise bu süreçte artmaktadır ${ }^{16}$. Dördüncü ve son neden ise hukukun üstünlüğü ile paralel bir şekilde gelişen mülkiyet haklarından, gelişmekte olan ülkelerde büyük ölçüde toplumun yüksek gelirli kesiminin yararlanıyor olmasıdır. Mülkiyet haklarının büyüme açısından öneminin anlaşılması ile birlikte gelişmekte olan ülkelerde özellikle yirminci yüzyılın ikinci yarısından itibaren mülkiyet hakları korumasını arttırmaya yönelik farklı düzenlemeler yapılmaktadır. Bu kapsamda, birçok gelişmekte olan ülke neoliberal dönüşüm sürecini benimsemekte ve yapısal uyum programlarını hayata geçirmektedir. Bu gelir grubundaki ülkelerin bozuk bir gelir dağılımına sahipken bu dönüşümü yaşıyor olması, mülkiyet haklarındaki iyileşmelerden büyük oranda toplumun yüksek gelirli kesiminin faydalanmasına ve böylece gelir dağılımı eşitsizliğinin artmasına neden olabilmektedir ${ }^{17}$.

Gelişmekte olan ülkelerde, kurumsal kalitedeki bir artışın gelir dağılımı üzerindeki bozucu etkisinin olası nedenleri yukarıda açıklanmıştır. Bu nedenler ışığında gelişmekte olan ülkelere yönelik bazı politika önerileri şöyle sıralanabilir:

Gelişmekte olan ülkelerde kayıt dışı sektör büyük olduğundan ve kurumsal kaliteyi arttırmaya yönelik reformlar bu sektörde çalışanlara ek maliyetler getireceğinden, kurumsal reformlarla birlikte bu sektörde faaliyet gösterenlerin refahını arttıracak ve onları resmi işlerde çalışmaya teşvik edecek politikalar uygulanmalıdır. Zira gelir dağılımı sorunu istihdam ihtiyaçları karşılanmadıkça ve kayıt dışı sektörde çalışanların savunmasızlığı giderilmedikçe çözülemeyecek$\operatorname{tir}^{18}$. Bu nedenle hükümetler geniş ölçekli ve sürdürülebilir iş fırsatlarının oluşturulmasını teşvik edecek uygun makroekonomik, sosyal, yasal ve politik ortamlar yaratmalıdır. Bunun yanında resmi olmayan işlerde çalışanlar eğitim, öğretim ve mikro finansmana erişebilmeli ve bu tür

\footnotetext{
${ }^{15}$ Daha ayrıntılı bilgi için Alesina ve Angeletos (2005)'in "Corruption, Inequality, and Fairness" adlı çalışması incelenebilir.

${ }^{16}$ Daha ayrıntılı bilgi Perera ve Lee (2013)'nin Have Economic Growth and Institutional Quality Contributed to Poverty and Inequality Reduction in Asia?" adlı çalışması incelenebilir.

17 Oğuz, 2017: 178.

${ }^{18}$ Daha ayrıntılı bilgi için Becker (2004)'ın "The Informal Economy” adlı çalışması incelenebilir.
} 
programlar, bu işçilerin yasal ve kurumsal çerçeveyle korunan resmi sektöre geçmelerine yardımcı olacak şekilde tasarlanmalıdır. Son olarak sosyal güvenlik primleri, vergiler, istihdamla ilgili bürokratik süreçler azaltılmalı ve işgücü piyasası daha esnek hale getirilmelidir.

Gelişmekte olan ülkelerde düşük gelirlilerin refahlarını iyileştirmeye yönelik büyük kamu projelerinde denetleme, teşvik ve yaptırım mekanizmaları daha sağlıklı bir şekilde kurgulanmalı ve süreç daha şeffaf yönetilmelidir. Böylece bir yandan bu projelerle birlikte ortaya çıkacak yolsuzluklar önlenirken bir yandan da bu projelerin amacına daha başarılı bir şekilde ulaşması sağlanabilir.

Gelişmekte olan ülkelerde görülen yolsuzluk gelişimsel türde olsa dahi gelir dağılımı eşitsizliğini azaltmak amacıyla yolsuzluğa izin verilmesi oldukça riskli bir çıkarım gibi görünmektedir. Zira uzun dönemde yolsuzluktaki artışlar ülkelerin daha zayıf bir kurumsal yapı ile karşı karşıya kalmasına ve bu nedenle kötü yönetişim/düşük verimlilik tuzağına yol açabilir. Gelişmekte olan ülkelerde gelir dağılımı eşitsizliğinin üstesinden gelinmesinin daha güvenli yolu; ülkeleri yolsuzlukla mücadeleye teşvik etmek ve aynı zamanda en düşük gelirli grupların üretkenliğini doğrudan arttıracak politikaları benimsemektir. Böylece, yolsuzlukla mücadele tedbirleri gelir dağılımı eşitsizliğinin arttıracak olsa dahi zarar, düşük gelir grubunda bulunan insanların beşeri sermayesindeki iyileşmelerle telafi edilebilir.

Gelişmekte olan ülkelerde iktisadi büyümeyi teşvik amacıyla mülkiyet hakları reformları tasarlanırken, kurumsal değişimin dağılımsal sonuçları göz ardı edilmemeli ve mülkiyet haklarındaki iyileşmelerin gelir dağılımı üzerindeki bozucu etkisini azaltmak amacıyla dengeleyici politikalar geliştirilmelidir. Bu kapsamda gelişmekte olan ülkelerde öncelikle mülkiyet haklarından alınan vergiler yeniden düzenlenebilir. Böylelikle bir yandan yüksek gelirlilerin mülkiyet haklarından elde ettiği getiri azaltılırken bir yandan da düşük gelirlilerin refahını arttırmaya yönelik kamu kaynakları arttırılabilir.

v) Gelişmiş ülkelerde finansal gelişmişlik indeksindeki bir artış gelir dağılımı eşitsizliğini arttırmaktadır. Bu bulgu, finansal gelişmenin, yoksulların pahasına zenginlere fayda sağlayacağını ileri süren "gelir eşitsizliğini genişletici hipotezi"'nin gelişmiş ülkelerde geçerli olduğu anlamına gelmektedir. Bu bulgular ışığında, gelişmiş ülkelerde finansal hizmetlerden-araçlardan daha çok varlıklarını teminat sunabilen, geri ödeme olasılığı daha yüksek, zengin ve iyi bağlantıları olanların faydalandığı söylenebilir. Bu sorunun üstesinden gelinebilmesi için gelişmiş ülkelerde, düşük gelir düzeyine sahip bireylerin finansal araçlara kolay ulaşımını ve finansal sisteme daha verimli bir şekilde entegre olmasını sağlayacak düzenlemelerin yapılması ve finansal okuryazarIığın yaygınlaştırılması gerekmektedir.

vi) Gelişmekte olan ülkelerde, gelişmiş ülkelerin tersine finansal gelişmişlik indeksindeki bir artış gelir dağılımı eşitsizliğini azaltmaktadır. Bu bulgu, gelişmekte olan ülkelerde "gelir eşitsizliğini daraltıcı hipotezi"'nin geçerli olduğu anlamına gelmektedir. Gelişmekte olan ülkelerde finansal gelişmenin, gelişmiş ülkelere göre daha düşük olduğu göz önünde bulundurulursa, temel finansal araçlardan (basit kredi, mevduat vb.) düşük gelir düzeyine sahip bireylerin daha fazla yararlandığı söylenebilir ${ }^{19}$. Ancak, finansal gelişmenin ileri aşamalarında, gelişmişülkelerde yaşanan sürecin gelişmekte olan ülkelerde yaşanmaması adına gelişmiş ülkelere yönelik politika önerilerinin gelişmekte olan ülkeler için de geçerli olduğunu belirtmek gerekir.

${ }^{19}$ Örneklemde yer alan gelişmiş ülkelerde ortalama finansal gelişmişlik indeksi 0.62 iken gelişmekte olan ülkelerde $0.27^{\prime}$ dir. 
vii) Hem gelişmiş hem de gelişmekte olan ülkelerde reel kişi başına gelirdeki bir artış, gelir dağılımı eşitsizliğini azaltmaktadır. Bu bulgu, 1988-2014 yılları arasında, ilgili ülkelerde gerçekleşen iktisadi büyümenin kapsayıcı bir büyüme olduğu anlamına gelmektedir. Kapsayıcı büyüme, genel olarak iktisadi büyüme sonucu ortaya çıkan fayda ve fırsatların toplumun her kesimine dengeli dağıldığı bir büyüme çeşidini ifade etmektedir ${ }^{20}$. Bu nedenle de ilgili ülkelerde iktisadi büyümenin devamını sağlayacak politikaların hem gelir artışı hem de daha eşitlikçi bir gelir dağılımı sağlayarak iki farklı kanaldan toplumsal refahı arttıracağı söylenebilir.

Çalışmada elde edilen tüm bulgular birlikte değerlendirildiğinde, yerel ve küresel düzeyde ekonomi politikalarına yön veren ana akım iktisadın kurumları dışlayıcı yaklaşımının ve her ülkeye benzer ekonomik çözümler uygulanmasına yönelik politikasının doğru olmadığı görülmektedir. Zira bu çalışmada kurumların gelir dağııımını belirleyen önemli unsurlardan biri olduğu ve kurumların gelir dağılımı üzerindeki etkisinin farklı gelişmişlik düzeyine sahip ülkelerde aynı olmadığı tespit edilmiştir. Bu nedenle ülkelerin iktisadi problemlerinin çözümüne yönelik politikalar oluşturulurken kurumsal yapı da dikkate alınmalı ve hukukun üstünlüğü, yolsuzluk, demokratik hesap verilebilirlik vb. gibi kurumsal yapıyı oluşturan faktörlerin iktisadi performansı farklı ülkelerde farklı yönde etkileyebileceği göz önünde bulundurulmalıdır.

${ }^{20}$ Daha ayrıntılı bilgi için Taşkın (2014)'ın “Türkiye'de Kapsayıcı Büyüme” adlı çalışması incelenebilir. 


\section{Eskişehir Osmangazi Üniversitesi IïB Dergisi}

\section{Kaynaklar}

Abrams, A. Burton; Lewis, A. Kenneth (1995), “Cultural and Institutional Determinants of Economic Growth: A CrossSection Analysis", Public Choice, Vol. 83 No. 2: 273-289.

Acemoglu, Daron; Johnson, Simon; Robinson, A. James (2002), "Reversal of Fortune: Geography and Institutions in the Making of the Modern World Income Distribution", The Quarterly Journal of Economics, Vol. 117 No. 4: 1231-1294.

Adams, Samuel; Klobodu, E.K. Mensah (2016), "Financial Development, Control of Corruption and Income Inequality", International Review of Applied Economics, Vol. 30 No. 6: 790-808.

Adeleye, Ngozi (2014), “The Determinants of Income Inequality and The Relationship to Crime" Yayınlanmış Yüksek Lisans Tezi, University of Sussex, United Kingdom.

Afesorgbor, K. Sylvanus; Mahadevan, Renuka (2016), “The Impact of Economic Sanctions on Income Inequality of Target States", World Development, Vol. 83: 1-11.

Afonso, António; Schuknecht, Ludger; Tanzi, Vito (2008), “Income Distribution Determinants and Public Spending Efficiency", ECB Working Paper Series, Working Paper No:861.

Alesina, Alberto; Angeletos, George-Marios (2005), "Corruption, Inequality, and Fairness", Journal of Monetary Economics, Vol. 52 No. 7: 1227-1244.

Amendola, Adalgiso; Easaw, Joshy; Savoia, Antonio (2013), "Inequality in Developing Economies: The Role of Institutional Development", Public Choice, Vol. 155: 43-60.

Andres, R. Antonio; Ramlogan-Dobson, Carlyn (2011), "Is Corruption Really Bad for Inequality? Evidence from Latin America", Journal of Development Studies, Vol. 47: 959-976.

Anyanwu, C. John; Erhijakpor, E.O. Andrew; Obi, Emeka (2016), "Empirical Analysis of the Key Drivers of Income Inequality in West Africa", African Development Review, Vol. 28, No. 1: 18-38.

Apergis, Nicholass; Dincer, C. Oğuzhan; Payne, E. James (2010), "The Relationship Between Corruption and Income Inequality in US States: Evidence from A Panel Cointegration and Error Correction Model", Public Choice, Vol. 145 No. 1-2: 125-135.

Arellano, Manuel; Bover, Olympia (1995), "Another Look At The İnstrumental Variables Estimation of Error Components Models", Journal of Econometrics, Vol. 68 No. 95: 29-51.

Barro, J. Robert (1991), "Economic Growth in a Cross Section of Countries", The Quarterly Journal of Economics, Vol. 106 No. 2: 407-443.

Barro, J. Robert (2000), "Inequality and Growth in a Panel of Countries", Journal of Economic Growth, Vol. 5: 5-32.

Baligh, Nafiseh; Piraee, Khosrow (2012), "Financial Development and Income Inequality Relationship in Iran”, MiddleEast Journal of Scientific Research (MEJSR), Vol. 12 No. 7: 906-914.

Baltagi, H. Badi (2013), Econometric Analysis of Panel Data, John Wiley\& Sons Ltd., Fifth Edition, Chichester.

Batuo, E. Michael; Asongu, A. Simplice (2015), "The Impact of Liberalisation Policies on Income Inequality in African Countries", Journal of Economic Studies, Vol. 42 No. 1: 68-100.

Benneth, L. Daniel; Nikolaev, Boris (2016), "Factor Endowments, The Rule of Law and Structural Inequality”, Journal of Institutional Economics, Vol. 12 No. 4: 773-795.

Bircan, Çağatay; Bruck, Tilman; Vothknecht, Marc (2010), "Violent Conflict and Inequality", Dıw Berlin, Discussion Papers 1013, Available at: http://ssrn.com/abstract=1639826.

Blundell, Richard; Bond, Stephen (1998), "Initial Conditions and Moment Restrictions in Dynamic Panel Data Models", Journal of Econometrics, Vol. 87, No. 98: 115-143.

Breusch, T. Stanley; Pagan, A. Rodney (1980), "The Lagrange Multiplier Test and Its Applications to Model Specification in Econometrics." The Review of Economic Studies, Vol. 47 No. 1: 239-253.

Brown, Christopher (2005), "Is There an Institutional Theory of Distribution?", Journal of Economic Issues, Vol. 39 No. 4: 915-931.

Carmignani, Fabrizio (2009), "The Distributive Effects of Institutional Quality When Government Stability is Endogenous", European Journal of Political Economy, Vol. 25: 409-421.

Chavance, Bernard (2009), Institutional Economics, Routledge, First Edition, New York.

Chong, Alberto; Calderon, Cesar (2000a), "Institutional Quality and Income Distribution" Economic Development and Cultural Change, Vol. 48: 761-786. 
Chong, Alberto; Calderon, Cesar (2000b), "Institutional Quality and Poverty Measures in a Cross-Section of Countries", Economics of Governance, Vol. 1: 123-135.

Chong, Alberto (2004), "Ineqality, Democracy, and Persistence: Is There a Political Kuznets Curve?", Economics \& Politics, Vol. 16: 189-212.

Chong, Alberto; Gradstein, Mark (2007), “Inequality and institutions”, Review of Economics and Statistics, Vol. 89: 454465.

Chudık, Alexander; Pesaran, M. Hashem, (2013). "Large Panel Data Models with Cross-Sectional Dependence: A Survey", http://www.dallasfed.org/assets/documents/institute/wpapers/2013/0153.pdf (Erişim: 10.01.2017).

Cogneau, Denis; Guénard, Charletto (2003), "Colonization, Institutions, and Inequality: A Note on Some Suggestive Evidence", https://ideas.repec.org/p/dia/wpaper/dt200305.html, (Erişim: 20.04.2016).

Delis, D. Manthos; Hasan, Iftekhar; Kazakis, Pantelis (2012), "Bank Regulations and Income Inequality: Empirical Evidence", Bank of Finland Research Discussion Papers, No. 18: 1-49.

Demir, Ömer, (1996), Kurumcu iktisat, Vadi Yayınları, Ankara.

Dias, Joilson; Tebaldi, Edinaldo (2012), “Institutions, Human Capital and Economic Growth: The Institutional Mechanism". Structural Change and Economic Mechanism, Vol. 23 No. 3: 300-312.

Gengenbach, Christian; Palm, C. Franz; Urbain, Jean-Pierre, (2009), "Panel Unit Root Tests in The Presence of CrossSectional Dependencies: Comparison and Implications for Modelling", Econometric Reviews, Vol. 29 No. 2: 111145.

Granger, W.J. Clive; Newbold, Paul (1974), "Spurious Regressions in Econometrics”, Journal of Econometrics, Vol. 2 No. 2: 111-120.

Gujarati, N. Domador; Porter, C. Dawn (2012), Temel ekonometri, Şenesen, Ümit; Şenesen, G. Gülay, (Çev.), Literatür Yayınları, 5. Baskı, İstanbul.

Gupta, Sanjeev; Davoodi, Hamid; Alonso-Terme, Rosa (2002), "Does Corruption Affect Income Inequality and Poverty?", Economics of Governance, Vol. 3: 23-45.

Haggard, Stephan; Tiede, Lydia (2011), "The Rule of Law and Economic Growth: Where are We?", World Development, Vol. 39 No. 5: 673-685.

Hall, E. Robert; Jones, I. Charles (1999), "Why Do Some Countries Produce So Much More Output Per Worker Than Others?", The Quarterly Journal of Economics, Vol. 114 No. 1: 83-116.

Hartmann, Dominik; Guevara, Miquel; Figueroa, C. Jara; Hidalgo, Cesar (2015), "Linking Economic Complexity, Institutions and Income Inequality", Mimeograph, http://arxiv.org/ftp/arxiv/papers/1505/1505. 07907.pdf, (Erişim: 09.08.2016).

Hodgson, M. Geoffrey (2000), "What Is the Essence of Institutional Economics?", Journal of Economic Issues, Vol. 34 No. 2: 317-329.

Kapetanios, George; Pesaran, M. Hashem; Yamagata, Takashi (2011), “Panels with Non-Stationary Multifactor Error Structures", Journal of Econometrics, Vol. 160 No. 2: 326-348.

Khan, H. Mushtaq (2009), "Governance, Growth and Poverty Reduction”, DESA Working Paper, No. 75: 1-17.

Khosroabadi, Mohammad; Zayandehroudi, Mohsen; Shakibaee, Alireza (2015), "Studying the Effect of Indicators of Good Governance on Income Distribution", Cumhuriyet University Faculty of Science Journal, Vol. 36, No. 3: 31003127.

Knack, Stephen; Keefer, Phillip (1997), "Does Social Capital Have an Economic Payoff? A Cross-Country Investigation", The Quaterly Journal of Economics, Vol. 112 No. 4: 1251-1288.

Lee, Chi-Chuan; Lee, Chien-Chiang (2018), "The Impact of Country Risk on Income Inequality: A Multilevel Analysis", Social Indicators Research, Vol. 136 No. 1: 139-162.

Li, Hongyi; Colin Xu, Lixin; Zou, Heng-fu (2000), “Corruption, Income Distribution, and Growth", Economics and Politics, Vol. 12 No. 2: 155-182.

Naschold, Felix (2002), "Why Inequality Matters for Poverty", Briefing Paper, https://www.odi.org/sites/odi.org.uk/files/odi-assets/ publications-opinion-files/3876.pdf, (Erişim: 26.04. 2017).

Nawaz, Saima (2015), "Growth Effects of Institutions: A Disaggregated Analysis", Economic Modelling, Vol. 45: 118-126. 


\section{Eskişehir Osmangazi Üniversitesi IïB Dergisi}

Nazlıoğlu, Şaban; Lebe, Fuat; Kayhan, Selim (2011), "Nuclear Energy Consumption and Economic Growth in OECD Countries: Cross-Sectionally Dependent Heterogeneous Panel Causality Analysis”, Energy Policy, Vol. 39: 66156621.

North, C. Douglas (1991), "Institutions", The journal of Econonomic Perspectives, Vol. 5 No. 1: 97-112.

North, C. Douglas, (1999), Kurumlar, Kurumsal Değisim ve Ekonomik Performans, Gül Çağalı Güven (Çev.) Cambridge University Press, Sabancı Üniversitesi Yayınları, İstanbul.

Oğuz, Onur (2017), "Gelir Dağılımı Adaletsizliğinin Kurumsal iktisat Yönünden Değerlendirilmesi: Ekonometrik Bir Uygulama”, Yayınlanmamış Doktora Tezi, Marmara Üniversitesi, Sosyal Bilimler Enstitüsü, İstanbul.

Oloufade, K. Djoulassi (2012), "Trade Openness, Conflict Risk and Income Inequality", http://dx.doi.org/10.2139/ssrn.2135222, (Erişim: 17.10.2017).

Park, H. Kang (1996), "Income Inequality and Economic Progress: An Empirical Test of the Institutionalist Approach", The American Journal of Economics and Sociology, Vol. 55, No. 1: 87-97.

Park, Cyn-Young; Marcedo, V. Rogelio (2015), "Financial Inclusion, Poverty, and Income Inequality in Developing Asia", ADB Economics Working Paper Series, No. 426: 1-19.

Pedroni, Peter (2001), "Purchasing Power Parity Tests in Cointegrated Panels", The Review of Economics and Statistics, Vol. 83 No. 4: 727-731.

Perera, D.H. Liyanage; Lee, H.Y. Grace (2013), "Have Economic Growth and Institutional Quality Contributed to Poverty and Inequality Reduction in Asia?", Journal of Asian Economics, Vol. 27: 71-86.

Pesaran, M. Hashem (2004), "General Diagnostic Tests for Cross Section Dependence in Panels", Cambridge Working Papers in Economics No. 435, University of Cambridge, and CES ifo Working Paper Series No. 1229.

Pesaran, M. Hashem (2006), "Estimation and Inference in Large Heterogeneous Panels with a Multifactor Error Structure", Econometrica, Vol. 74 No. 4: 967-1012.

Pesaran, M. Hashem (2007), "A Simple Panel Unit Root Test in The Presence of Cross-Section Dependence”, Journal of Applied Econometrics, Vol. 22: 265-312.

Pesaran, M. Hashem; Ullah, Aman; Yamagata, Takashi (2008), “ A Bias-Adjusted LM Test of Error Cross-Section Independence", Econometrics Journal, Vol. 11:105-127.

Pesaran, M. Hashem; Yamagata, Takashi (2008), “Testing Slope Homogeneity in Large Panels", Journal of Econometrics, Vol. 142: 50-93.

Piketty, Thomas; Goldhammer, Arthur, (2014a), Capital in the Twenty-First Century, Cambridge, Massachusetts: The Belknap Press of Harvard University Press.

Piketty, Thomas; Saez, Emmanuel (2014b), "Inequality in the Long Run", The Since of Inequality, Vol. 344 No. 6186: 838-843.

Political Risk Service (2016). "International Counrty Risk Guide (ICRG)" http://www.prsgroup.com/about-us/our-twomethodologies/icrg" (Erişim: 15.01.2016).

Reuveny, Rafael; Li, Quan (2003), "Economic Openness, Democracy, and Income Inequality: An Empiricial Analysis", Comparative Political Studies, Vol. 36 No. 5: 575-601.

Rodrik, Dani; Subramanian, Arvind; Trebbi, Francesco (2004), "Institutions Rule: The Primacy of Institutions Over Geography and Integration in Economic Development", Journal of Economic Growth, Vol. 9 No. 2: 131-165.

Sadorsky, Perry (2013), "Do Urbanization and Industrialization Affect Energy Intensity in Developing Countries?", Energy Economics, Vol. 37: 52-59.

Sahota, G. Sing (1978), “Theories of Personal Income Distribution: A Survey," Journal of Economic Literature, Vol. 16 No. 1: 1-55..

Schneider, Friedrich (2010), "The Influence of Public Institutions on the Shadow Economy: An Empirical Investigation for OECD Countries", Review of Law \& Economics, Vol. 6 No. 3: 441-468.

Shafique, Saima; Haq, Rashida (2006), "Governance and Icome Inequality”, The Pakistan Development Review, Vol. 45 No. 4: 751-760.

Smith, L. Vanessa; Leybourne, Stephen; Kim, Tae-Hwan; Newbold, Paul (2004), “More Powerful Panel Data Unit Root Tests with an Application to Mean Reversionin Real Exchange Rates", Journal of Applied Econometrics, Vol. 19: $147-170$ 
Solt, Frederick. Standardizing World Income Inequality Database, http://myweb.uiowa.edu/fsolt/papers/Solt2014, Erişim Tarihi: (Erişi: 20.01.2016).

Stiglitz, E. Joseph (2015), The Price of Inequality: How Today's Divided Society Endangers Our Future, Kindle Edition.

Stiglitz, E. Joseph, (2016),"Inequality and Economic Growth", Rethinking Capitalism, Michael, jacobs ve Mariana, Mazzucato, (Ed.). WileyBlackwell, New Jersey, 134-155.

Taşkın, Temel (2014), Türkiye'de Kapsayıcı Büyüme, Ekonomi Notları, TCMB, Ankara.

Tatoğlu, F. Yerdelen, (2013a), Panel Veri Ekonometrisi, Beta Basım, 2. Baskı, İstanbul.

Tatoğlu, F. Yerdelen, (2013b), Ileri Panel Veri Analizi, Beta Basım, 2. Baskı, İstanbul.

Wagle, R. Udaya (2009), "Inclusive Democracy and Economic Inequality in South Asia: Any Discernible Link?", Review of Social Economy, Vol. 67, No. 3: 329-357.

Westerlund, Joakim; Edgerton, L. David L. (2007), “A Panel Bootstrap Cointegration Test”, Economics Letters, Vol. 97 : 185-190.

Westerlund, Joakim (2008), "Panel Cointegration Test of The Fisher Effect", Journal of Applied Econometrics, Vol. 23: 193-233.

http://info.worldbank.org/governance/wgi/index.aspx\#home (Erişim: 05.08. 2016).

Veblen, Thorstein (1908), “On the Nature of Capital”, The Quarterly Journal of Economics, Vol. 22 No. 4: 517-542.

Veblen, B. Thorstein (1919), The Place of Science in Modern Civilisation and Other Essays, New York: Huebsch.

Zhou, Yixiao; Song, Ligang (2016), "Income inequality in China: Causes and Policy Responses", China Economic Journal,Vol. 9, No. 2: 186-208. 
Eskişehir Osmangazi Üniversitesi IißBF Dergisi 